\title{
Chapter 21 \\ Galls of the Temperate Forest of Southern South America: Argentina and Chile
}

\author{
Carolina Quintero, Lucas A. Garibaldi, Audrey Grez, Carlo Polidori, \\ and José Luis Nieves-Aldrey
}

\begin{abstract}
South American temperate forests are of special conservation concern due to their highly endemic flora and fauna, and the occurrence of unique plant-animal interactions. Yet, knowledge regarding gall inducers diversity is limited although increasing rapidly in the last two decades. Here, we performed a review of the literature, supplemented with field collected data by the authors, in order to provide the most up to date knowledge of gall inducers' diversity associated with native woody species of the temperate forest of Chile and Argentina. We present data for 90 morphospecies of galls associated with 39 host-plant species (21 genera, 15 families), spanning insects and arachnids of at least 6 orders and nematodes. Most of this richness is associated to the best surveyed host-plant genus, Nothofagus, with up to 43 morphospecies of galls in just 8 dominant tree species. Moreover, we provide evidence that gall species richness across all woody host-plant species decreases with elevation, probably driven by decreased temperature and number of available host-plant species. However, this overall trend vary among host plant species and
\end{abstract}

\footnotetext{
C. Quintero $(\bowtie)$

Laboratorio Ecotono, CONICET-INIBIOMA, Universidad Nacional del Comahue, Quintral 1250, 8400 San Carlos de Bariloche, Río Negro, Argentina e-mail: quintero.carolina@gmail.com
}

L.A. Garibaldi

Laboratorio Ecotono, CONICET-INIBIOMA, Universidad Nacional del Comahue, Quintral 1250, 8400 San Carlos de Bariloche, Río Negro, Argentina

Sede Andina, Universidad Nacional de Río Negro (UNRN) and Consejo Nacional de Investigaciones Científicas y Técnicas (CONICET),

Mitre 630, CP 8400 San Carlos de Bariloche, Río Negro, Argentina
A. Grez
Departamento de Ciencias Biológicas Animales, Facultad de Ciencias Veterinarias y Pecuarias, Universidad de Chile, Avda. Santa Rosa, 11735 La Pintana, Santiago, Chile
C. Polidori • J.L. Nieves-Aldrey
Departamento de Biodiversidad y Biología Evolutiva, Museo Nacional de Ciencias Naturales (CSIC), C/José Gutiérrez Abascal 2, ES-28006 Madrid, Spain 
scales of observation. Overall, the study of gall diversity and the biotic and abiotic factors that shape their distribution in these austral forests offer an exciting and fertile field for future research. Besides emphasizing the need for more in depth taxonomic and diversity studies of the gall fauna of these forests, we propose several future lines of research that promise to further elucidate our understanding of the evolution of plant-gall interactions in these forests.

Keywords Nothofagus • Aditrochus - Temperate forest • Elevation gradient • Latitudinal gradient

\subsection{Introduction}

The temperate forest of South America stretches as a narrow belt, $100-250 \mathrm{~km}$ wide, along the Andes from $37^{\circ}$ to $55^{\circ} \mathrm{S}$, surrounded by the Pacific Ocean to the west and south and a series of arid and semi-arid ecosystems to the east and north (Fig. 21.1) (Cabrera and Willink 1973; Grau 1995). Its highly endemic biota evolved under a warmer climate than today during much of the Cenozoic, and thus, these forests are nowadays considered a biogeographically isolated biome (Villagrán and Hinojosa 1997). The particular biogeographic history, highly endemic flora, and past and current climate of these forests have shaped distinct gall communities compared to those found in the Neotropics and temperate forests in other regions (e.g., Fernandes and Price 1988; Price et al. 1998; Espírito-Santo and Fernandes 2007). Nonetheless, many general gall biodiversity and geographic distribution patterns reported elsewhere (Fernandes and Price 1988; Fernandes and Lara 1993; Price et al. 1998; Blanche 2000; Fagundes and Fernandes 2011), may also apply to this largely unexplored ecosystem.

Here, we review the literature documenting taxonomic diversity of gall inducers associated with native woody species, and supplement this review with recent field surveys assessing gall inducers diversity, higher-trophic interactions, and geographic distribution patterns. In particular, we focus our attention on the gall inducers' diversity associated with Nothofagus spp. (Nothofagaceae), the most widely distributed tree genus in the region, and identify a rich galling insect fauna ( $40 \mathrm{spp}$.), of seemingly constrained taxonomic diversity. In particular, the evolutionary and ecological importance of the best known Nothofagus' galls, induced by Aditrochus (Hymenoptera, Chalcidoidea), which in turn hosts a rich inquiline and parasitoid community, is emphasized. Moreover, we provide evidence that gall species richness across all woody host-plant species decreases with elevation, probably driven by decreased temperature and number of available host-plant species. However, this overall trend may vary depending on the scale of observation. Finally, we discuss how systematic, phylogenetic, evolutionary and ecological studies on gall insect biodiversity in South America's temperate forest can improve our understanding of the evolution of plant-gall interactions worldwide and suggest future lines of research. 


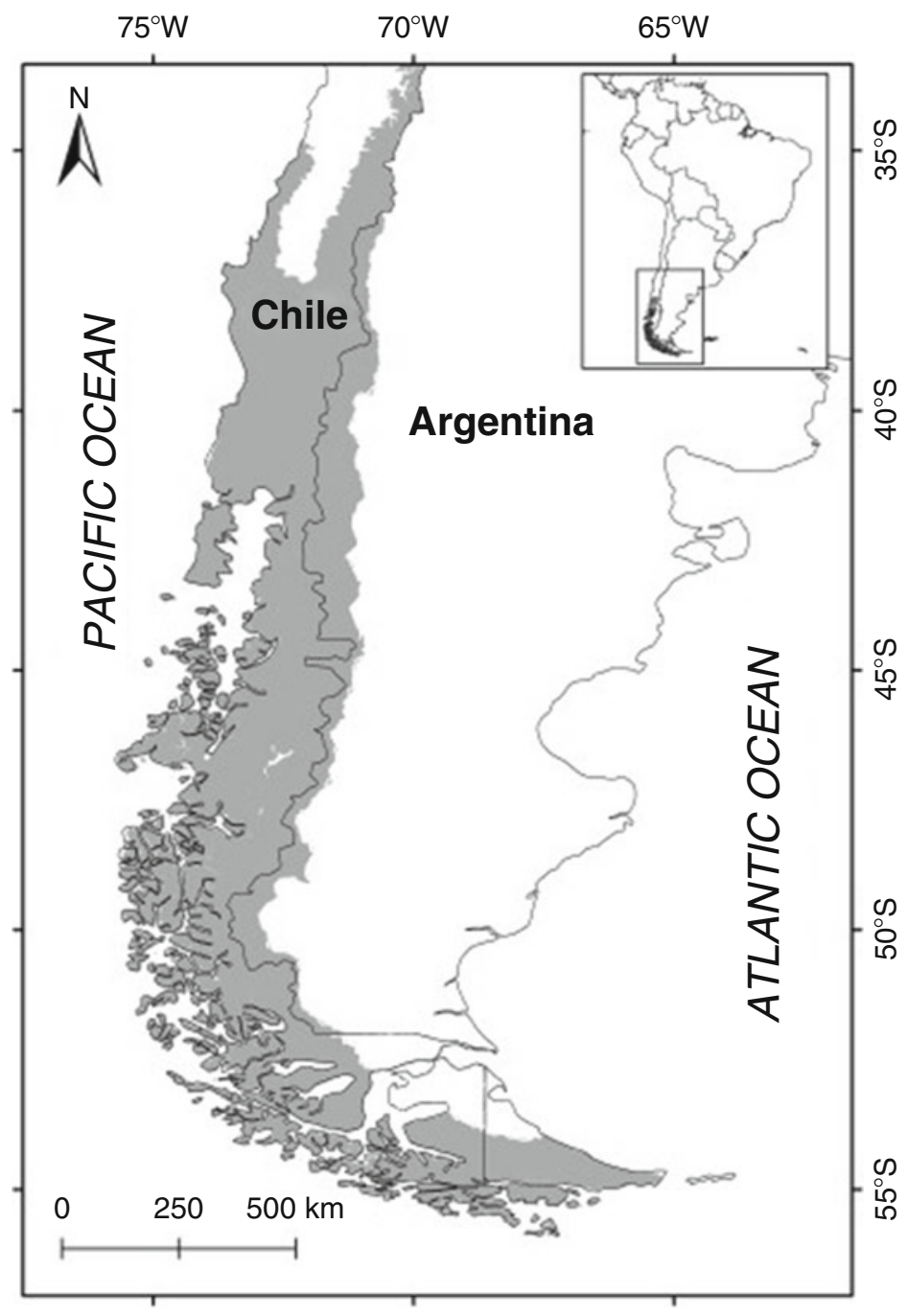

Fig. 21.1 The temperate forest of southern South America (TFSSA, in grey) is located along the Chilean and Argentinean Andes. Ice fields and other non-vegetated land cover types within the forest perimeter are omitted for simplicity

\subsection{The Temperate Forests of Southern South America (TFSSA)}

South American temperate forests encompass a flora rich in endemisms, with at least three endemic angiosperm families (Misodendraceae, Gomortegaceae, and Aextoxicaceae) and several endemic genera (34\% of the woody flora) and species 
(90\% of the seed plant species) (Arroyo et al. 1996; Villagrán and Hinojosa 1997). This biome, currently isolated, was once connected with the Neotropics, during much of the Paleocene and early Eocene (65-40 Ma), when this land was covered by a continuous tropical-like forest extending north and south what is today southern South America (Arroyo et al. 1996; Markgraf et al. 1995; Hinojosa and Villagrán 1997). That warmer past can be revealed through its congeneric relationship with extant tropical taxa (Arroyo et al. 1996), the unexpectedly high incidence of epiphytism, unique plant-animal mutualisms (Armesto and Rozzi 1989; Aizen and Ezcurra 1998; Aizen et al. 2002), and anatomical characters such as leaf-margin of woody dicotyledoneous species (Aizen and Ezcurra 2008), among others.

The long-lasting geographical isolation of these forests resulted from the separation and drifting away of South America from Antarctica ( 30 Ma) and by the rain shadow created by the uplift of the Andes ( $15 \mathrm{Ma}$ ) (Villagrán and Hinojosa 1997; Aizen and Ezcurra 2008). Subsequently, the establishment of the Antarctic circumpolar current and the extensive glaciations during the last million years resulted in the cooling of southern South America, causing the extinction of many tropical plant taxa ( $\sim 60 \%$ of paleoforests' genera) and a strong north to south temperature gradient (Villagrán and Hinojosa 1997; Aizen and Ezcurra 2008). Hence, the current distribution of the biota of this "biogeographic island" depends on the dispersal ability of the surviving species to recolonize the land from multiple glacial refugia (Markgraf et al. 1995). Today, the biota of the TFSSA is composed by a high proportion of shared Neotropical genera (28\%), now separated by the so-called "Arid-Diagonal of South America", Australasian genera (20\%) currently 10,000 km away (Villagrán and Hinojosa 1997), and several taxa from the Holarctic region that migrated southwards across the cold corridor of the Andes from late Miocene ( 11 Ma) onwards (Villagrán and Hinojosa 1997; Aizen and Ezcurra 2008).

The climate of this region is characterized by three key gradients. First, there is a poleward decrease in annual temperature, which originates a sequence of bioclimatic zones: Mediterranean, Temperate and Sub-Antarctic. Second, there is a poleward increase in annual precipitation with rainfall uniformly distributed throughout the year at the southern most latitudes. And third, there is a pronounced west-to-east gradient of decreasing precipitation ( 4,000 to $400 \mathrm{~mm}$ ), originated from air masses coming from the Pacific that encounter the orographic barrier of the Andes, which creates a rain shadow effect east of the mountains. This west-to-east precipitation gradient limits the occurrence of the TFSSA to just $10-45 \mathrm{~km}$ wide following the Andes into Argentinean territory (Fig. 21.1) (Amigo and Rodriguez-Guitian 2011). Finally, a common feature in all these bioclimatic zones is the strong influences of the Oceans (Pacific and Atlantic) that moderate temperature fluctuations (Amigo and Rodriguez-Guitian 2011). All these climatic characteristics lead to a marked north-to-south and west-to-east decrease in the richness of the flora and fauna of the TFSSA. For example, Kuschel (1960) reported that the insect fauna of the Magellanic forest is essentially a small subset of the richer Valdivian forest to the north.

Among its unique flora, Patagonian forest canopies are commonly dominated by Nothofagus species (Nothofagaceae), which include evergreen and deciduous trees known as southern beeches. This trans-Antarctic genus has 35 described 
species distributed among cold temperate South America, New Zeeland, Australia, New Guinea, and New Caledonia. In Chile and Argentina there are ten dominant or co-dominant canopy tree species extending from $35^{\circ}$ to $56^{\circ} \mathrm{S}$ (ca. $2,500 \mathrm{~km}$, see Fig. 21.1) in the southern cone of South America (Rodríguez and Quezada 2003). The most common and widespread of these species are: N. pumilio (Poepp and Endl.) Krasser (lenga), N. dombeyi (Mirb.) Blume (coihue), N. betuloides (Mirbel) (coigüe de Magallanes), and $N$. antarctica (G. Forster) Oerst. (ñirre or ñire) (Hoffmann 1978). Other species are N. alpina (raulí), N. obliqua (Mirb.) Oerst (roble), N. alessandrii Espinosa (ruil), N. nitida (Phil.) Krasser (roble de Chiloé), and N. glauca (Phil.) Krasser (hualo). One last recently described species, $N$. rutila Ravenna, closely allied to N. obliqua, is restricted to Valparaíso region in Chile (Ravenna 2000), while another described species, N. leonii Espinosa, is suggested to be a hybrid of N. glauca and N. obliqua (Hoffmann 1982).

Nothofagus forests are located in one of the 34 biodiversity hotspots for conservation priorities (Mittermeier et al. 2004; Arroyo et al. 2004); but are currently threatened by deforestation, fragmentation, forest fires and the introduction of exotic species (Armesto et al. 2009; Echeverría et al. 2006; Grez et al. 2006 and references therein). Nothofagus forests hold a special conservation concern given that, as compared to other worldwide temperate biomes, the TFSSA has one of the highest reported rates of animal pollinated and seed dispersed floras (Armesto et al. 2009). Approximately, $85 \%$ of the woody genera in these forests have flowers visited by vertebrate or invertebrate pollinators and more than $50 \%$ of the woody genera have fleshy fruits indicating a high dependence on vertebrate dispersers (Aizen et al. 2002). Yet, these interactions might be particularly fragile given that they are highly asymmetric (i.e. one bird pollinator for every 14 plant species and four seed dispersers for every 23 plant species; Aizen et al. 2002). Lastly, plant-animal interactions involving insects are one of the least explored aspects of the ecology of the TFSSA, but recent studies highlight their high diversity and ecological relevance (Aizen et al. 2002), emphasizing the need to protect these forest and the expectedly rich associated insect fauna. Hence, given its species richness, its biogeography and current geographic extent and its ecological role, this chapter focuses mostly on the biodiversity of gall inducers associated with the genus Nothofagus and, to a lesser extent, to the most common native understory woody species under Nothofagus canopies.

\subsection{Gall Inducer Diversity of the TFSSA}

Although considerable efforts to describe the diversity of gall inducers for Argentina and Chile were made before 1930 (e.g. Molina 1782; Philippi 1873; Neger 1900; Rübsaamen 1902; Trotter 1902; Kieffer 1904a, b; Kieffer and Herbst 1905, 1906, 1909, 1911; Kieffer and Jörgensen 1910; Manganaro 1914; Tavares 1915; Porter 1920a, b, 1930; and see the key reference Houard 1933 for a synthesis), up to the beginning of this century gall inducers were one of the least explored guilds of all 
phytophagus insects associated with the flora of these austral forests. Take for example the case of the genus Nothofagus. While there is an extensive database of the insect fauna associated with these species (Gentili and Gentili 1988; McQuillan 1993; Grandon 1996; Carrillo and Cerda 1987), adding up to at least 30 genera worldwide (McQuillan 1993), only two morphospecies of galls were cited in McQuillan (1993). This report, in fact, missed two other gall inducers previously described for $N$. obliqua, such as the gall midge Rhopalomyia nothofagi (Diptera, Cecidomyiidae) (Madrid 1974) and a Nematode, Tylenchus arboricolus (Tylenchidae) (Cobb 1922). Yet, most of the biodiversity of gall species associated to Nothofagus spp. were described in the last two decades (e.g. Moreno et al. 1999; Cerda and Angulo 2002; Nieves-Aldrey et al. 2009; Sandoval and Beeche 2010; Buffington and Nieves-Aldrey 2011). Finally, for other genera besides Nothofagus, our knowledge is even scarcer. Only gall faunas of Colliguaja spp. (Euphorbiaceae); Schinus spp. (Anacardiaceae), Baccharis spp. (Asteraceae) and Prosopis spp. (Fabaceae) have been more extensively studied (Stuardo 1930; Drathen 1958; Díaz and De Santis 1975; Díaz 1981; Martinez et al. 1992; Fernandes et al. 1996; Fuentes-Contreras et al. 1999; Gonzales et al. 2005; Barrancos et al. 2008), together with some invading gall wasps associated with the exotic host-plant Hypochaeris glabra (Asteraceae) (Hym., Cynipidae: Phanacis hypochoeridis, Pujade-Villar and Díaz 2001; NievesAldrey and Grez 2007).

Therefore, to provide the most up to date knowledge of the gall inducers' biodiversity of the TFSSA, we perform a literature review and present new unpublished field data collected by the authors of this chapter. For the past 12 years, we performed sporadic and systematic surveys of gall inducers associated with Nothofagus species and other native Patagonian genera, ranging from $35^{\circ}$ to $56^{\circ} \mathrm{S}$, in both Chile and Argentina. In general, the surveys were conducted during the austral summers and encompassed all nine Nothofagus species (N. obliqua, $N$. pumilio, $N$. dombeyi, $N$. antarctica, $N$. glauca, $N$. alessandrii, $N$. betuloides, $N$. nitida and N. alpina) as well as other common native genera, sampled in national parks and reserves of Chile (Regions: VII Maule, IX Araucanía, X Los Lagos, XI Aisén and XII Magallanes) and Argentina (Andean regions located across five provinces: Neuquén, Río Negro, Chubut, Santa Cruz and Tierra del Fuego). Plants were sampled by walking linearly in transects during at least $1 \mathrm{~h}$ (see Price et al. 1998). The trees or shrubs were visually searched for galls, with plants and galls collected and photographed. If possible, branches of galled plants were dried and saved into a herbarium collection. In addition, if the galls were from the current season, they were dissected in the laboratory for adult and larval identification at family level. The gall species were identified by external morphological traits of the galls, the larvae and the host plant.

This work revealed a total of 90 morphospecies of gall inducers on 39 native host-plant species (21 genera, 15 families), of which approx. half of them are described in association with Nothofagus spp. (Tables 21.1 and 21.2). This rich gall fauna comprise all major gall inducers taxa, with records spanning at least five orders of insects (Diptera, Hymenoptera, Lepidoptera, Hemiptera, Homoptera), one of arachnids (Acari), and few species of nematodes (Tables 21.1 and 21.2). 

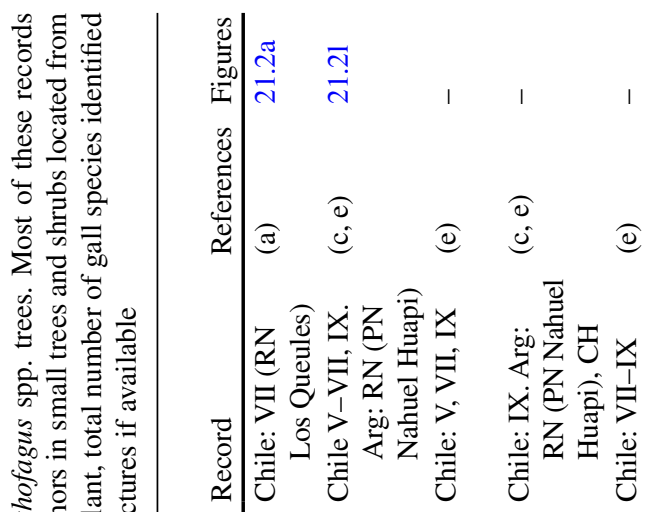

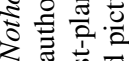

on 0 药 青完过

<. 은

它

西

¿

to

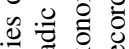

政

की

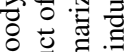

3 吾言

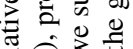

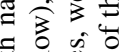

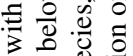

उ

帘

卷

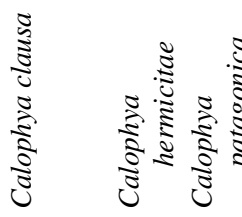

ब

ปุ

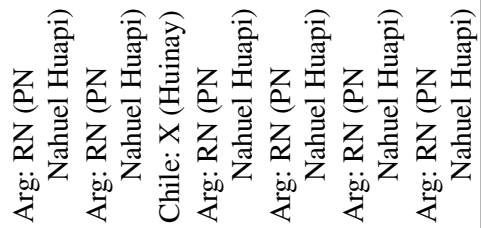

के है न

पे

की

䗡

于要节

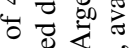

:

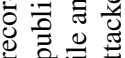

를

층

है $\overline{0}$

क

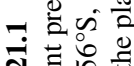

งิ๊ำ

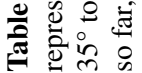

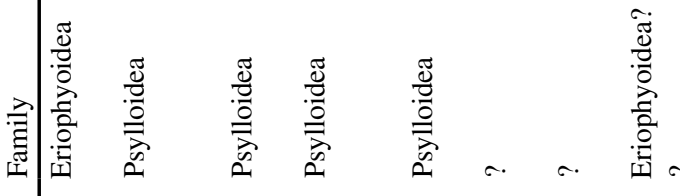

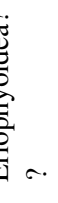

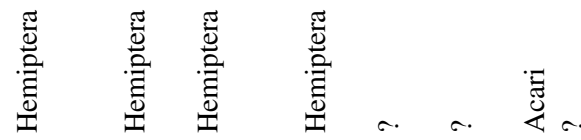

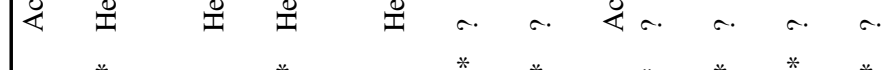




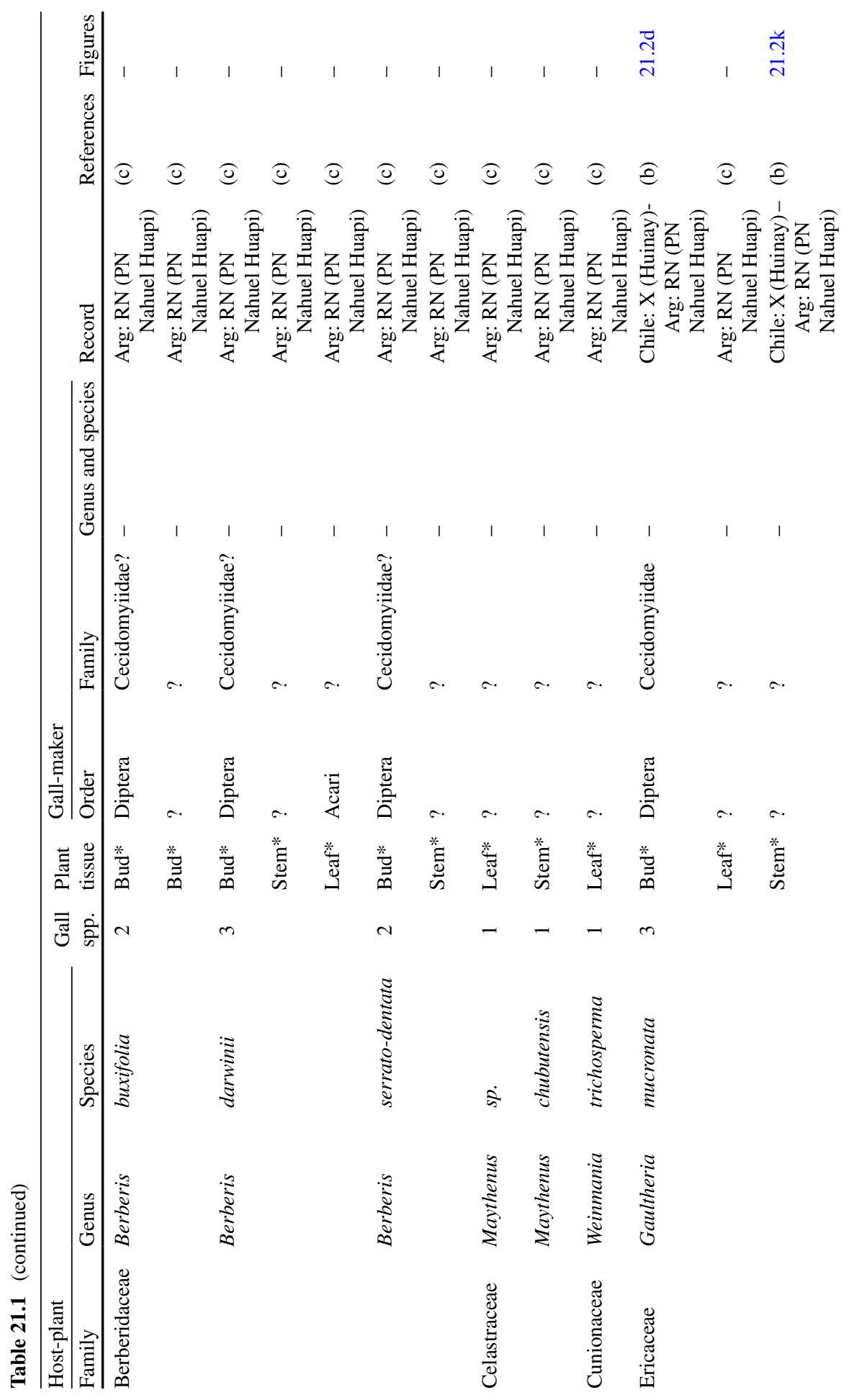




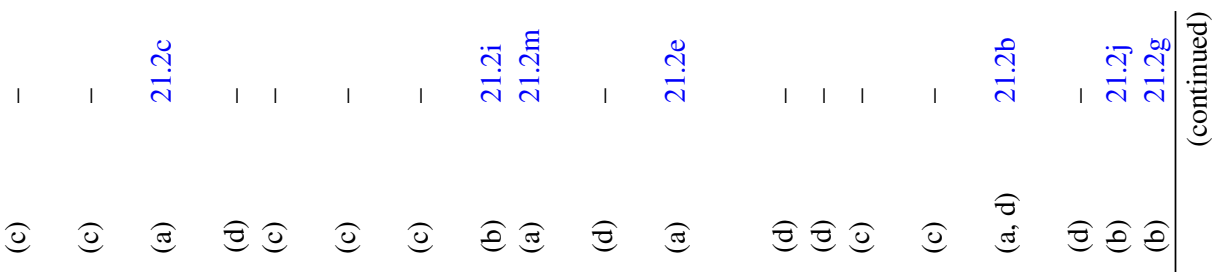

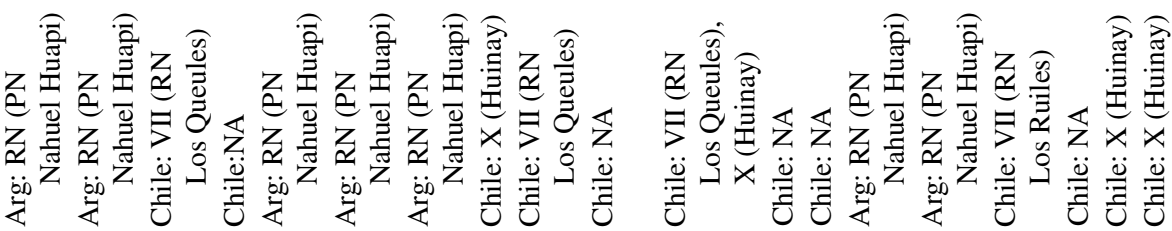

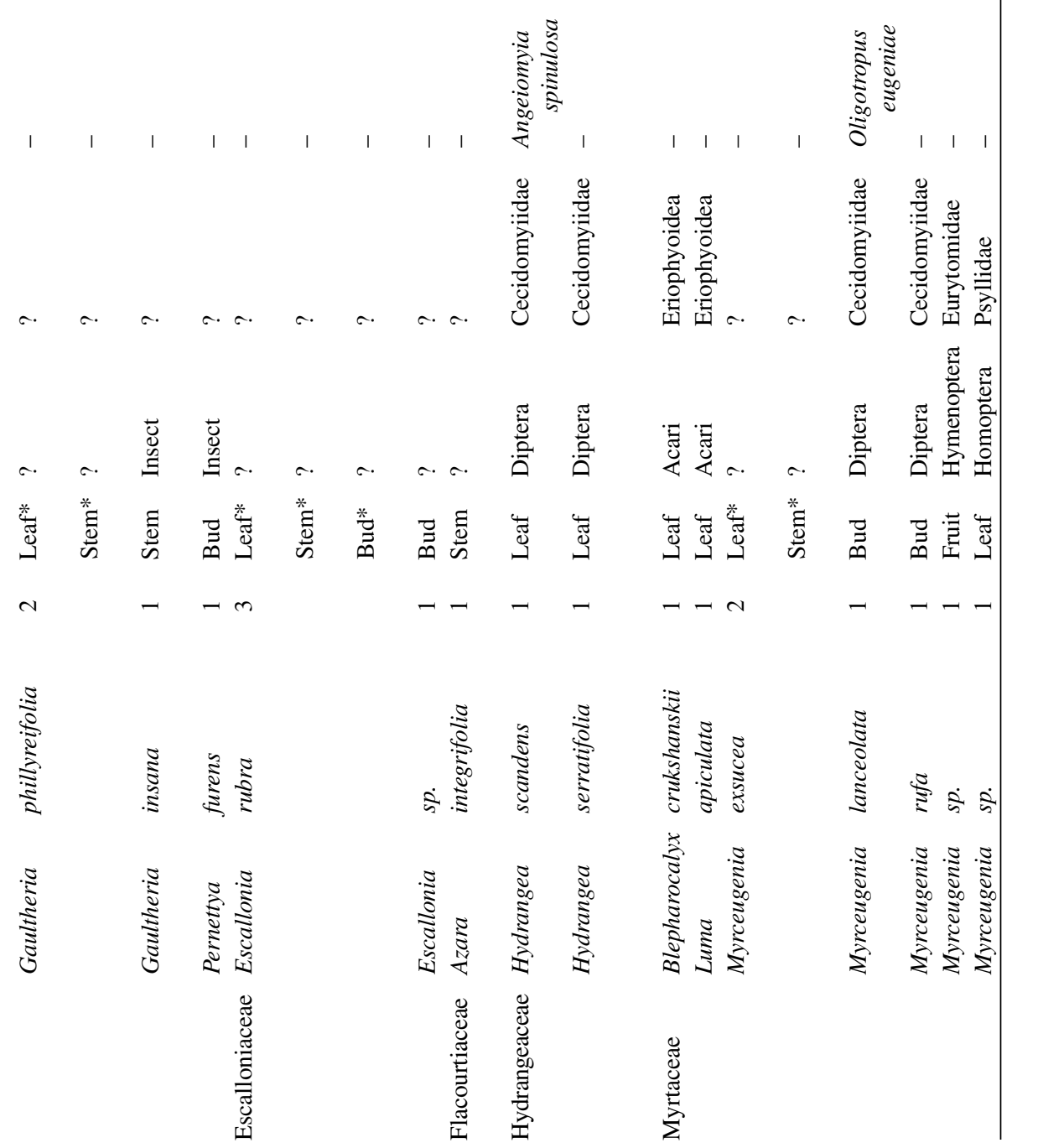




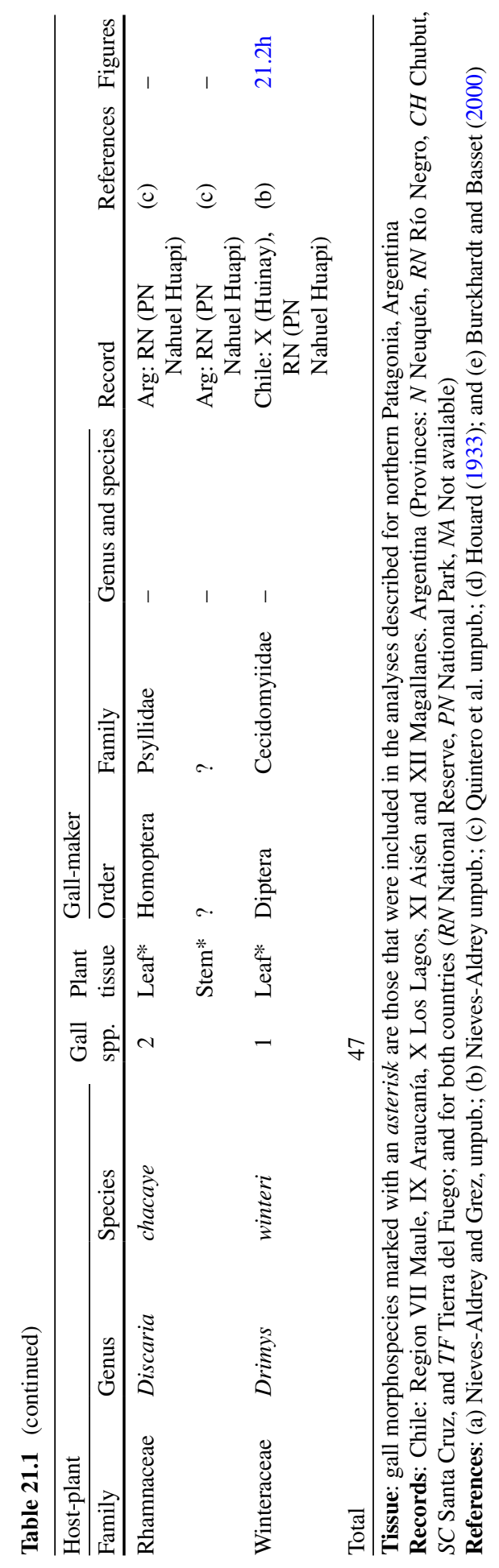




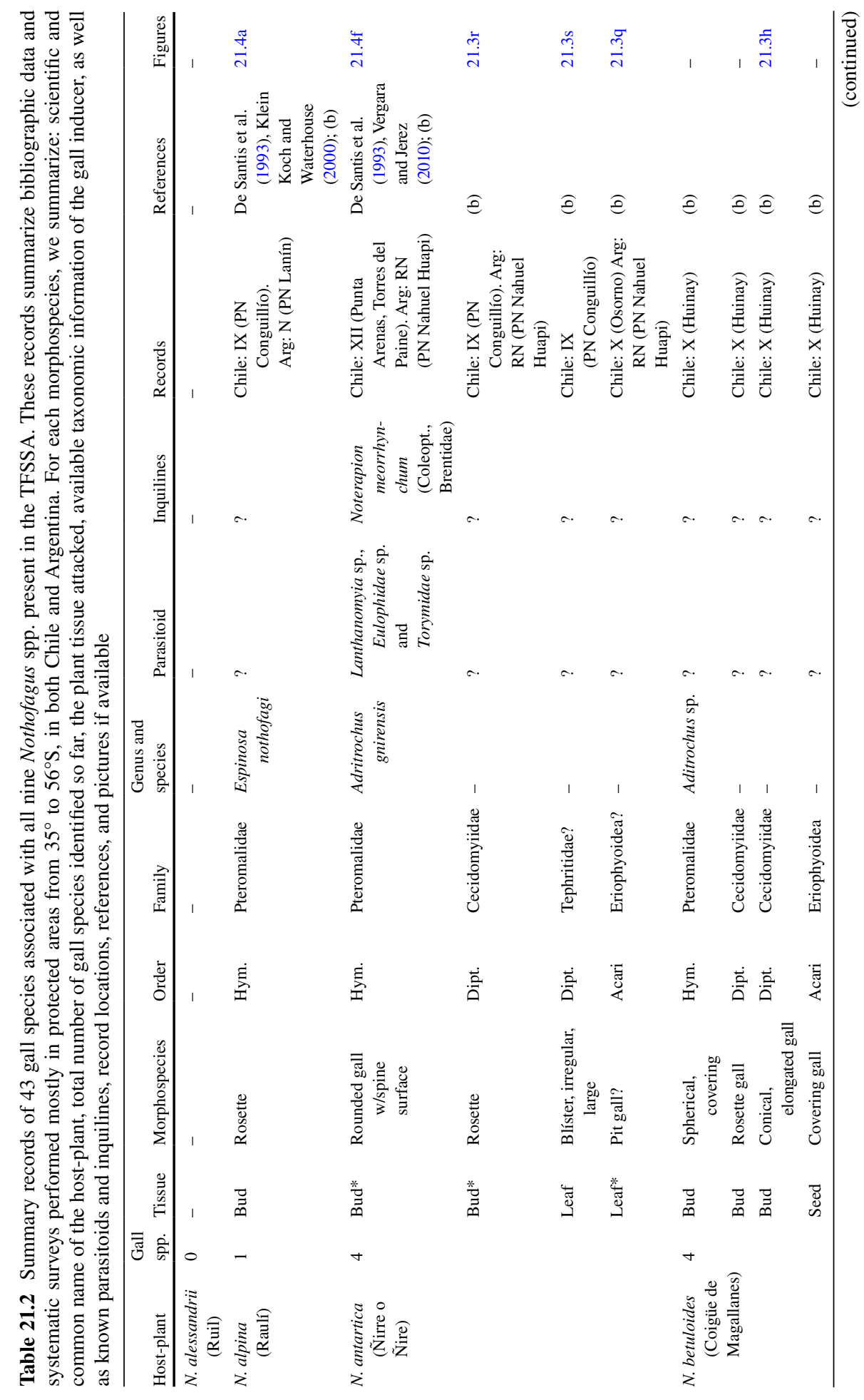




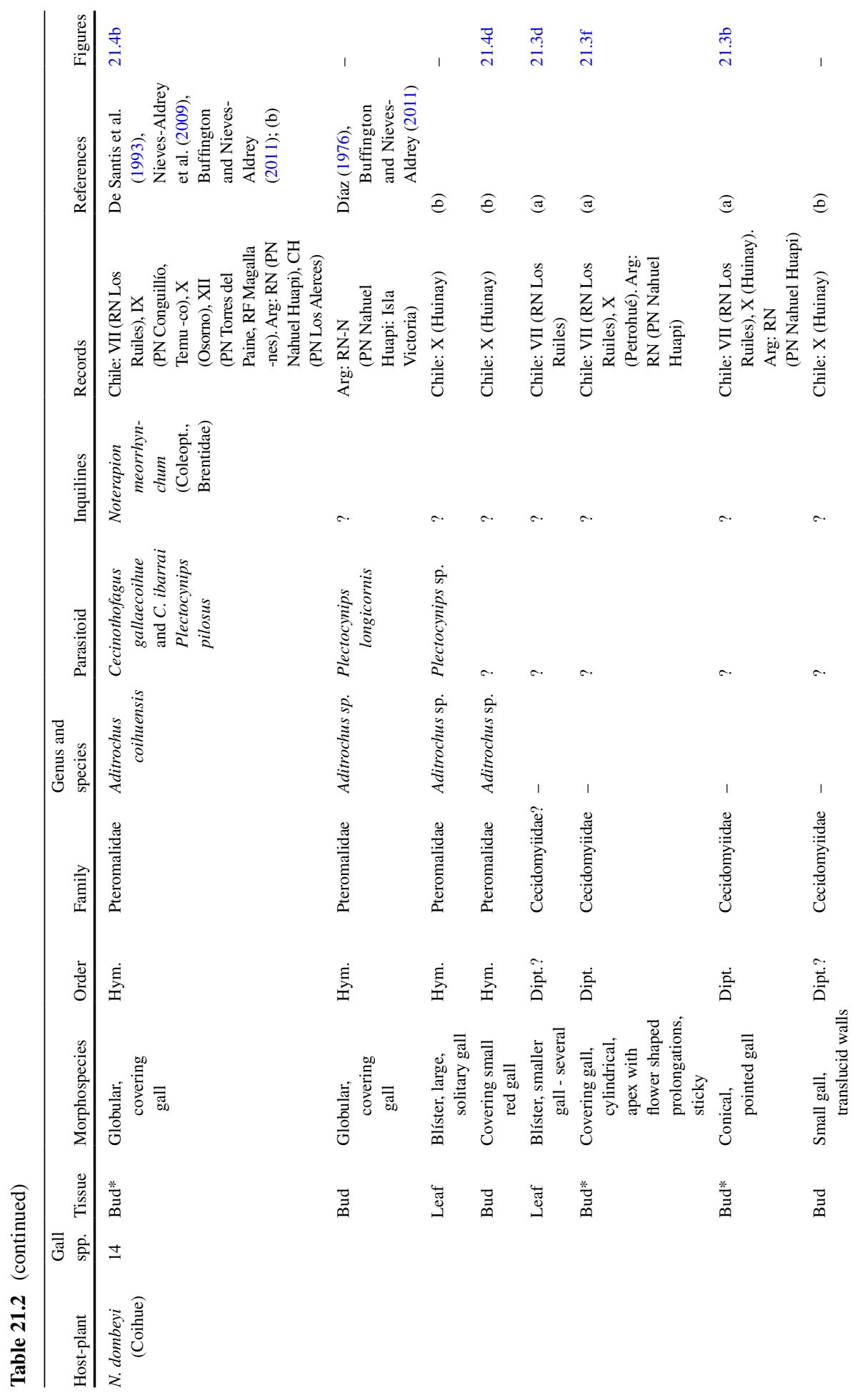




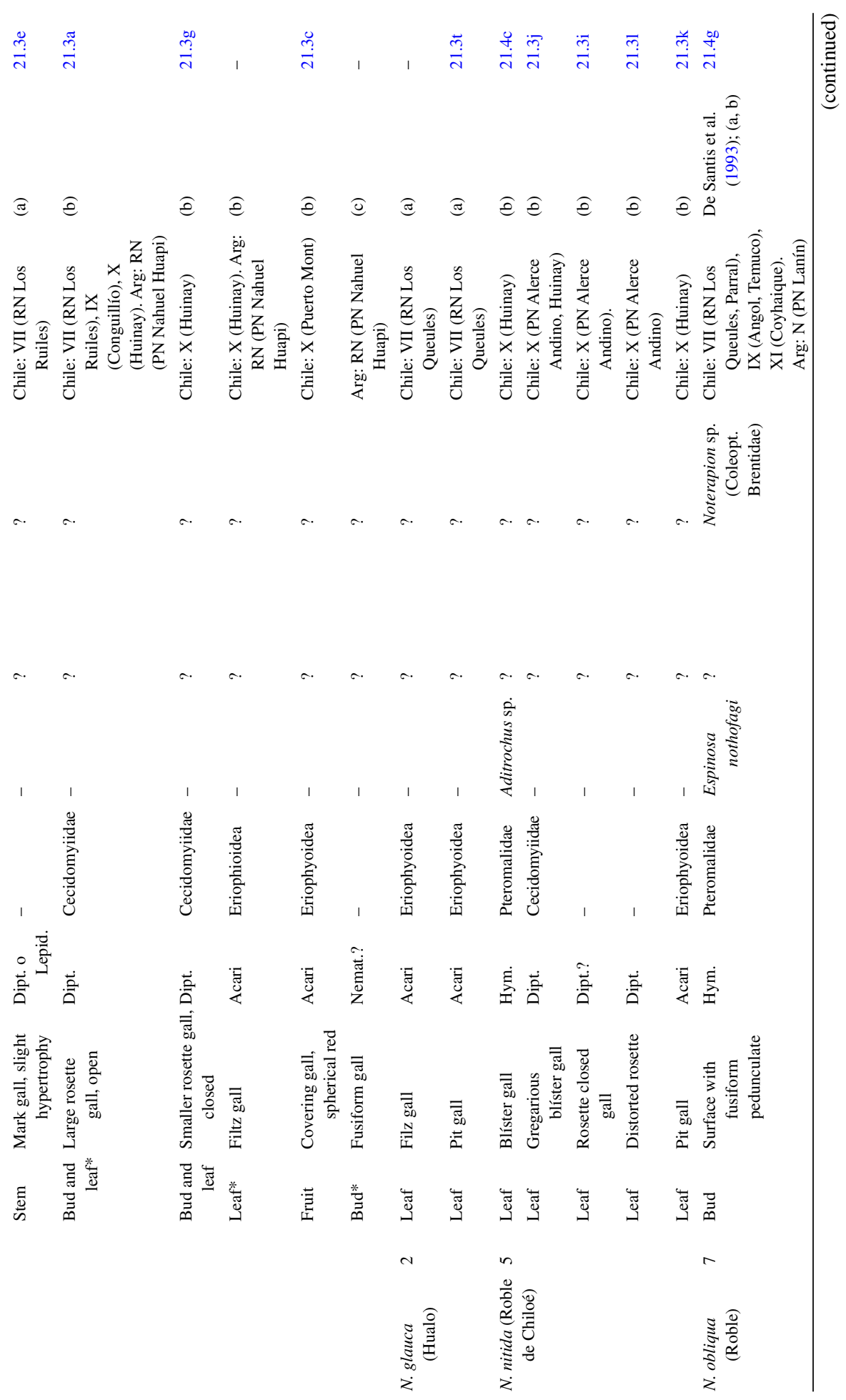




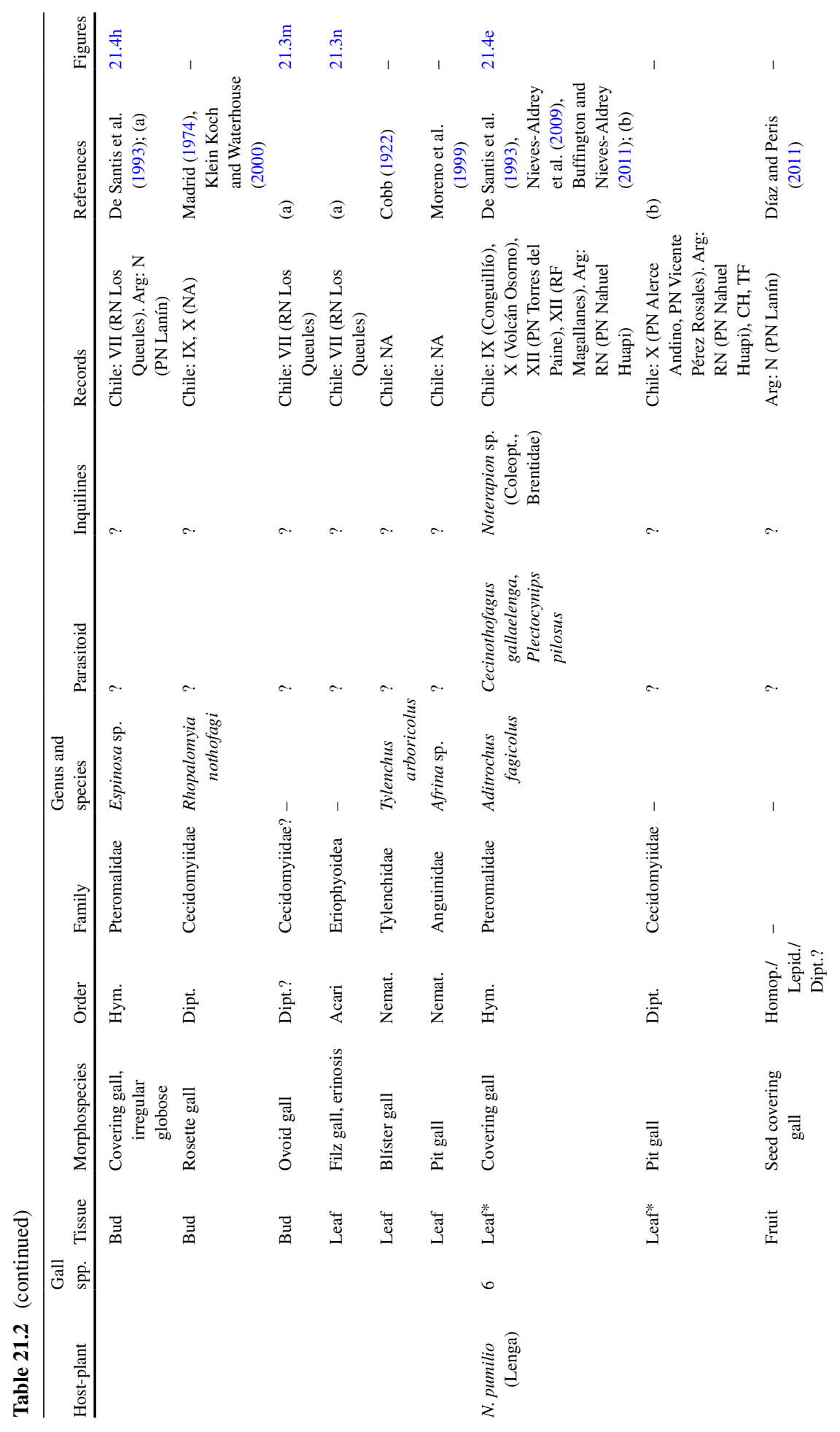




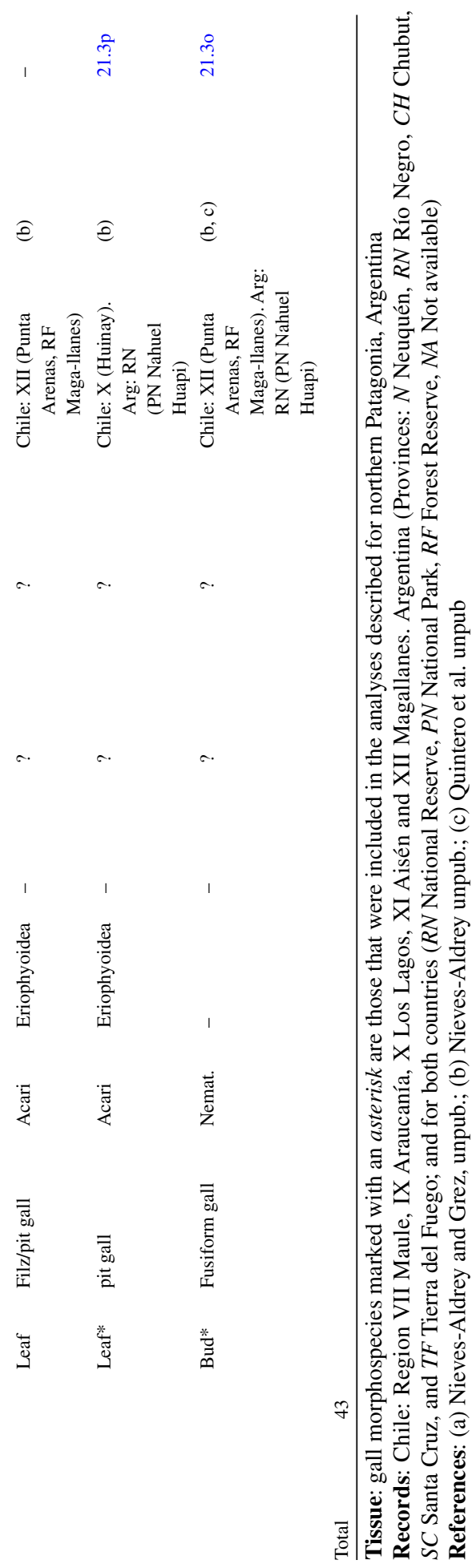


Yet, further taxonomic studies are required, given that a bit more than $20 \%$ of the gall fauna has been identified to genera and/or species level, and $60 \%$ to order and/ or family level.

Outside of gall species associated to Nothofagus spp. (Table 21.1, Fig. 21.2), summary statistics of gall inducers' diversity are hard to interpret as no systematic or exhaustive surveys had been conducted for the entire region. However, few general trends emerge from Table 21.1. First, most host-plant species that presented galls had one or two gall morphospecies each, with only four plant species reaching 3-5 gall morphospecies, suggesting that systematic surveys of this flora may lead to higher gall diversity than that known today. Second, plant genera with higher number of gall inducers were the most specious genus surveyed so far (e.g., Berberis, Escallonia, and Gaultheria), potentially supporting the positive relationship seen between host-plant diversity and gall diversity in other ecosystems (e.g., EspíritoSanto and Fernandes 2007). Third, despite that species identity is only known in 6 out of the 47 described species, and around half are identified to order and/or family level, a potentially high taxonomic diversity of gall inducers is expected given the diversity of tissues attacked and the presence of most gall inducer orders. Fourth, except for one report on fruits, gall inducers attacked mostly leaf blades $(\sim 50 \%)$, followed by stems (26\%), and buds (23\%). Finally, no ecological knowledge regarding diversity of parasitoids and/or inquilines had been described for any of these gall species.

For the genus Nothofagus, and in contrast to what we observed for all other native host-plant genera, extensive field surveys supplemented by our literature review has revealed a surprisingly rich gall fauna, adding up to 43 different gall species (Table 21.2, Figs. 21.3 and 21.4). The Nothofagus species with the higher number of galls was $N$. dombeyi, with 14 different galls, followed by $N$. obliqua with $7, N$. pumilio with 6 , and $N$. nitida with 5 . Two species counted with four gall species each ( $N$. antarctica, $N$. betuloides), while $N$. glauca and $N$. alpina reported two and one gall species, respectively, and no galls were reported for $N$. alessandrii (Table 21.2, Fig. 21.5). The most attacked tissues by gall inducers were buds and leaf blades ( $>45 \%$ each), and to a lesser extent stems, fruits and seeds with one or two records each. Taxonomically, ca. $40 \%$ of the galls are induced by midge galls (Diptera, Cecidomyiidae), $25 \%$ by chalcidoid wasps (Hymenoptera, Pteromalidae), $23 \%$ by mite galls (Acari, Eriophyoidea), around $10 \%$ by Nematoda, and less than $5 \%$ by Lepidoptera or unknown insect orders (Fig. 21.5). This diverse gall fauna seems to be, at the same time, taxonomically restricted to few genera (Table 21.2). For instance, for the best studied galling order on Nothofagus spp., Hymenoptera, the 11 gall species described are restricted to two genera (Aditrochus and Espinosa), suggesting a common ancestor and radiation within the Nothofagus genus.

The galls induced by species of Aditrochus (Hymenoptera, Pteromalidae) on South American Nothofagus are of particular interest (see Table 21.2 and Fig. 21.4), hosting some taxa of Chalcidoidea and Cynipoidea that are potentially crucial for the understanding of their early evolution (Nieves-Aldrey et al. 2009). These complex galls (Fig. 21.4) have been object of considerable debate concerning which are the gall inducer agents. Galls have been attributed to cynipids of the genus Paraulax 

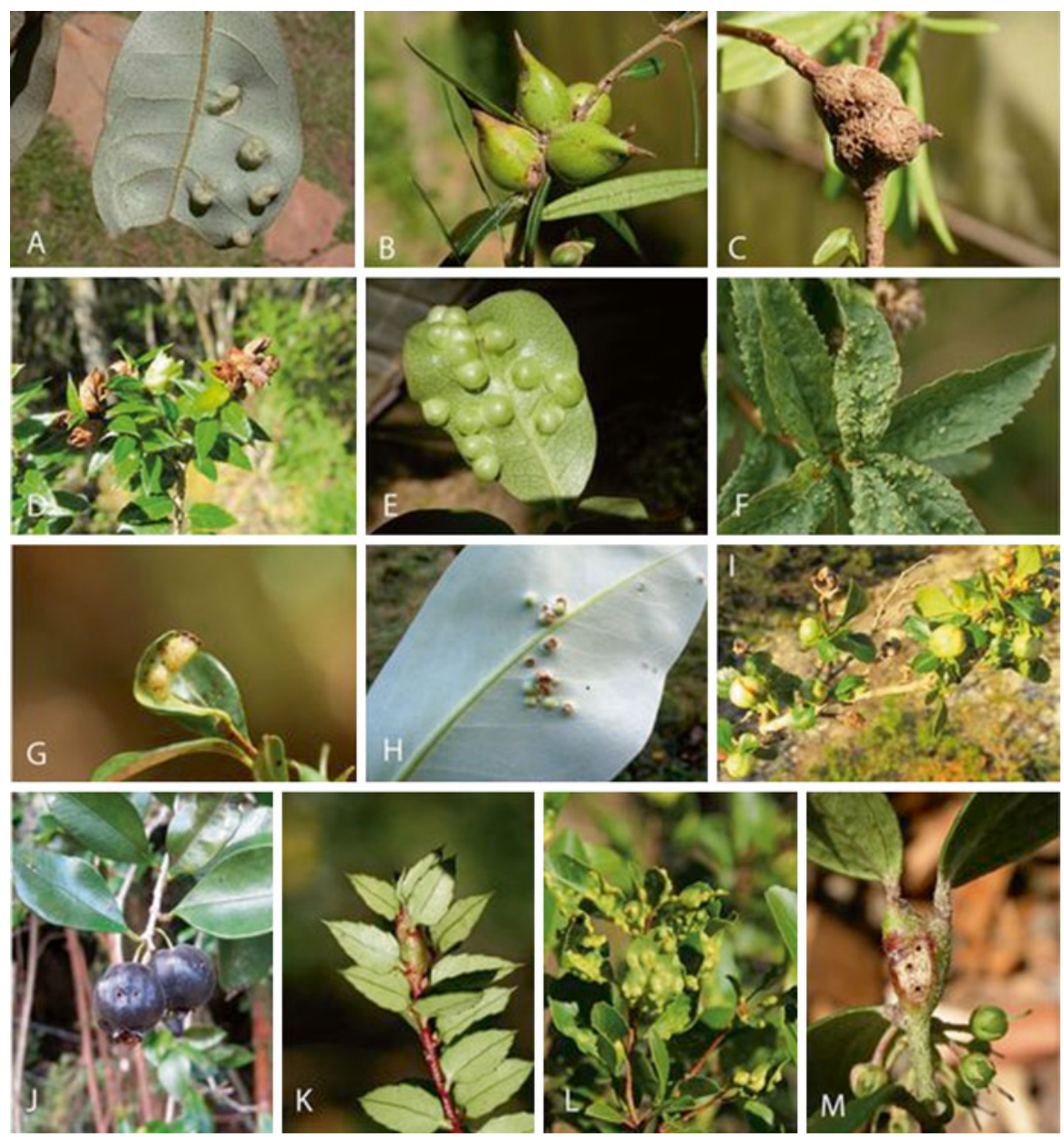

Fig. 21.2 Galls on plant species of the temperate forest of southern South America. (a) dipterocecidia on leaf of Aextoxicon punctatum (Aextoxicaceae); (b) galls of Cecidomyiidae en Myrceugenia lanceolata (Myrtaceae); (c) galls on stems of Gaultheria insana (Ericaceae); (d) galls on buds of Gaultheria mucronata (Ericaceae); (e) leaf galls on Hydrangea sp. (Hydrangeaceae); (f) acarocecidia on Senecio sp. (Asteraceae); (g) leaf gall of a psyllid on Myrceugenia sp. (Myrtaceae); (h) leaf galls on Drymis winteri (Winteraceae); (i) galls on Escallonia sp. (Escalloniaceae); (j) fruits of Myrceugenia sp. (Myrtaceae) with galls of Eurytomidae; (k) galls on twigs of Gaultheria mucronata (Ericaceae); (l) leaf gall of a psyllid on Schinus patagonicus (Anacardiaceae); (m) stem gall on Azara integrifolia (Flacourtiaceae) (Photos by J.L. Nieves-Aldrey, except for 2L by C. Quintero)

(Ronquist 1999; Ronquist and Nieves-Aldrey 2001; Csoka et al. 2005; Liu and Ronquist 2006), to an uncertain hymenoptera agent (De Santis et al. 1993) or even to a beetle of the Apionidae family (Kissinger 2005). Recently, Nieves-Aldrey et al. (2009) found strong evidence of the galls being induced by pteromalids of the genus 

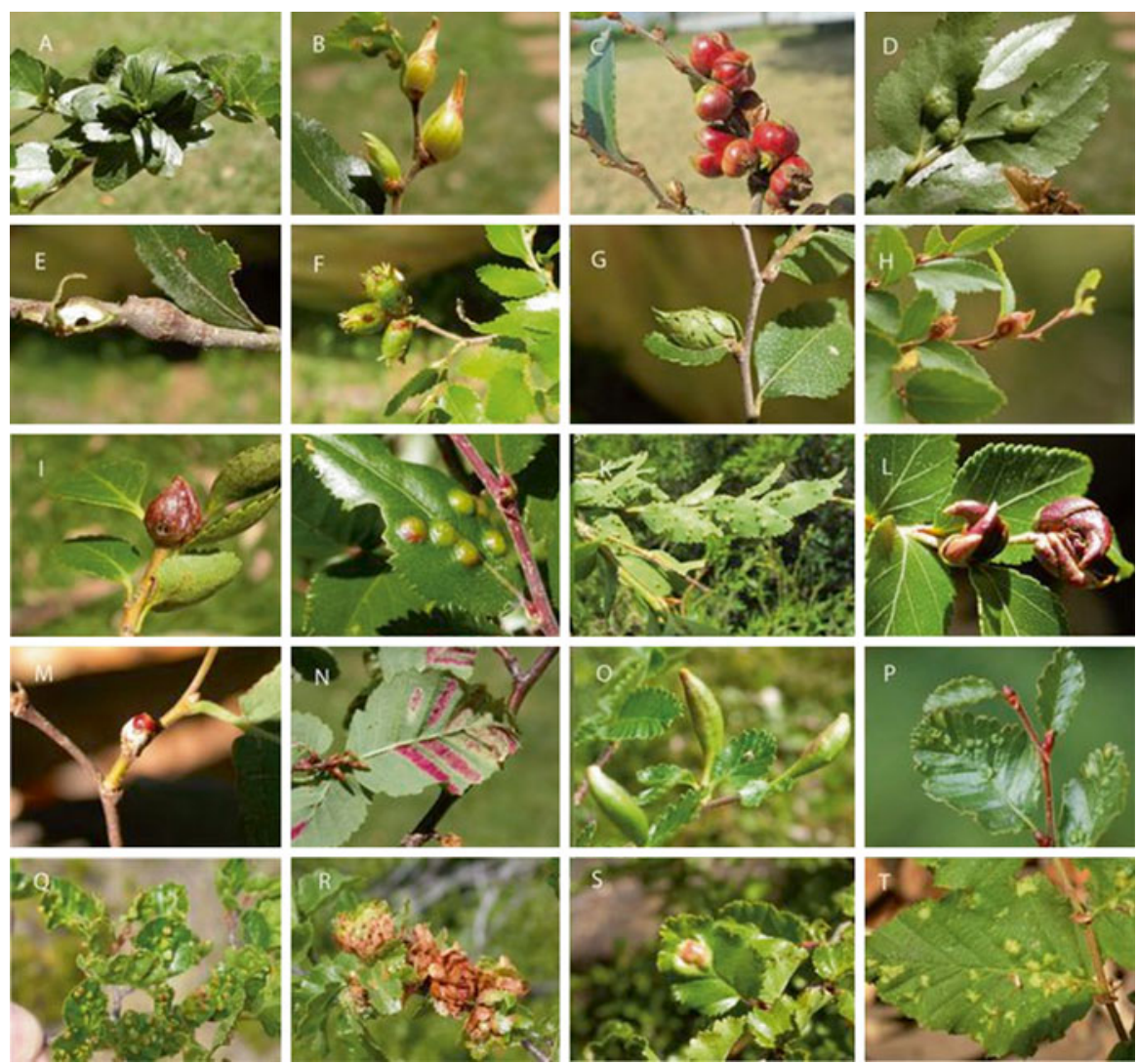

Fig. 21.3 Galls on Nothofagus species (Nothofagaceae) of the temperate forest of southern South America, excepting those induced by Aditrochus species (Pteromalidae): (a) dipterocecidia on Nothofagus dombeyi; (b) midge galls on N. dombeyi; (c) acarocecidia in seeds of N. dombeyi; (d) dipterocecidia on N. dombeyi; (e) galls of undetermined insects in stems of $N$. dombeyi; (f) galls of Cecidomyiidae on N. dombeyi; (g) dipterocecidia on N. dombeyi; (h) dipterocecidia on $N$. betuloides; (i) dipterocecidia on N. nitida; (j) dipterocecidia en leafs of $N$. nitida; (k) acarocecidia on N. nitida; (I) dipterocecidia on N. nitida; (m) dipterocecidia on N. obliqua: (n) acarocecidia on N. obliqua; (o) galls induced by nematode on N. pumilio; (p) acarocecidia on N. pumilio; (q) acarocecidia on $N$. antarctica; (r), (s) dipterocecidia on N. antarctica; (t) acarocecidia on N. glauca (Photos by J.L. Nieves-Aldrey)

Aditrochus (Pteromalidae, Ormocerinae), with the associated cynipid Cecinothofagus and the figitid Plectocynips being inquilines or parasitoid, as well as the apionids of the genus Noterapion Kissinger (Coleoptera, Brentidae, Apioninae) being inquilines (Table 21.2, see also Kissinger 2005; La Salle 2005; Buffington and Nieves-Aldrey 2011).

All in all, the diversity of gall species on Nothofagus is far above the richness observed for any other host-plant genus survey to date from the TFSSA. Until 

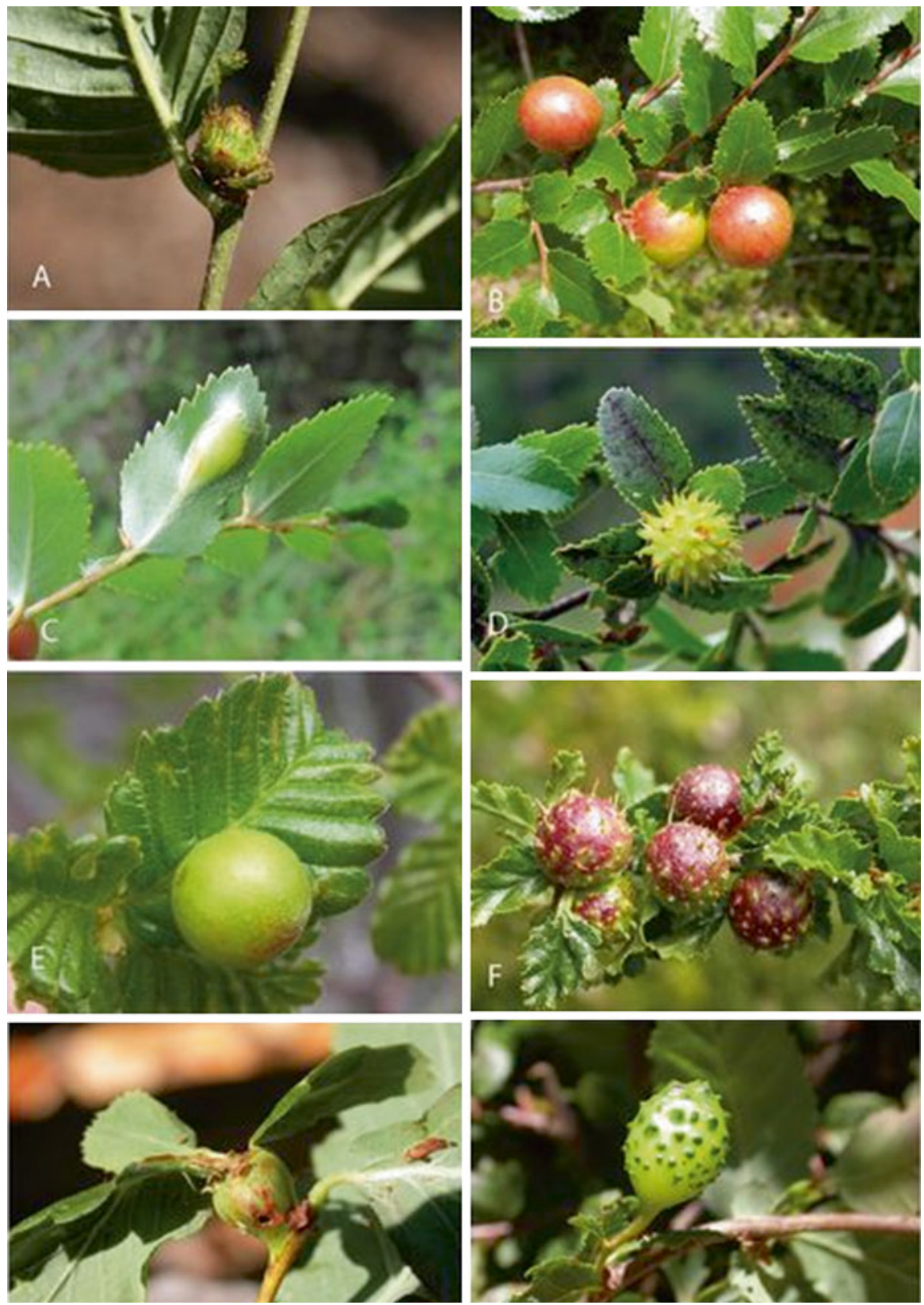

Fig. 21.4 Galls on Nothofagus species (Nothofagaceae) of the temperate forest of southern South America induced by pteromalid species (Hym., Pteromalidae): (a) Espinosa nothofagi Gahan on N. alpina; (b) Aditrochus coihuensis Ovruski on N. dombeyi; (c) Aditrochus sp. indet. on N. nitida; (d) Aditrochus sp. indet. on N. dombeyi; (e) Aditrochus fagicolus Ruebsaamen on N. pumilio; (f) Aditrochus gnirensis Fidalgo on N. antarctica; (g) Espinosa sp. on N. obliqua; (h) Espinosa sp. on N. obliqua (Photos by J.L. Nieves-Aldrey) 


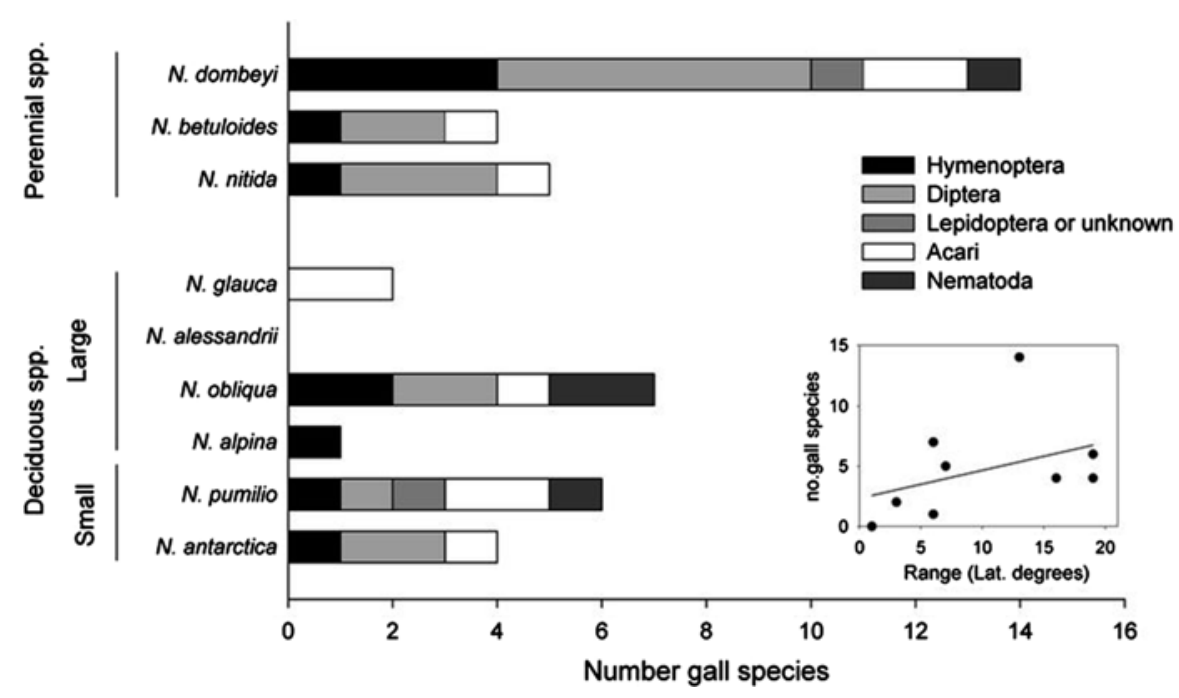

Fig. 21.5 Number of gall species and morphospecies per insect order for each Nothofagus (Nothofagaceae) host-plant species present in the TFSSA. Nothofagus species are arranged into three large ecological groups: perennial species associated to the "Valdivian Region", and deciduous species further separated into large-leaved trees restricted to "Mediterranean-like climates" and small-leaved trees typical of the "Subantarctic region". In addition, their top to bottom order within each of these three groups corresponds, more or less, to the species occurrence from north to south. The small panel to the right shows the relationship between number of gall morphospecies and host-plant distributional range [calculated in number of covered latitudinal degrees, from Amigo and Rodriguez-Guitian (2011)], for all nine Nothofagus species. See Table 21.1 for further taxonomic and ecological information of gall morphospecies

now, it is unknown whether this remarkable biodiversity of gall inducers associated to South American Nothofagus is rare or not, as compared to the fauna of gall inducers in Australasian Nothofagus, since this guild has not been widely study in other Nothofagus species outside of the TFSSA. Similarly, which biotic and/or abiotic conditions favor the disparity in gall inducers' diversity among Nothofagus spp. is also still unknown. In this respect, no mayor trends have emerged yet (Fig. 21.5). First, there is not a clear pattern in gall species richness or diversity between perennial and deciduous Nothofagus species, or between small- and large-leaved deciduous trees. Second, in contrast to expected (Ribeiro and Basset 2007), Nothofagus species located in mostly Mediterranean-like climates (i.e. large-leaved deciduous trees) did not have higher richness as compared to those adapted to mostly temperate and boreal climates. Finally, although there is a trend suggesting that species more widely distributed host richer gall faunas than those spatially restricted (Fig. 21.5), there is not a significant relationship between these variables $(r=0.42, N=9, p=0.26)$, as tested by a simple Pearson correlation coefficient between Nothofagus spp. galling richness and geographical range. 
It is important to mention though, that discussions regarding causal factors explaining differences in Nothofagus gall species richness need to take into account that the differences in gall species richness reported this far may just reflect differences in sampling effort, and not true ecological differences. Nonetheless, in a more general study on richness of herbivorous insects on Nothofagus trees, Lavandero et al. (2009) found that phytochemical uniqueness of the host plants was an important factor to explain insect species richness. For example, they show that $N$. alessandrii, the species with the most unique chemistry, had very few and mostly specialized herbivores, whereas $N$. dombeyi, with the least unique chemistry, had the highest number of related insect species. These findings are consistent with our dataset of the guild of gall-inducing organisms on Nothofagus (Table 21.2, Fig. 21.5), suggesting that intrinsic biotic factors, such as plant defenses, may play a key role structuring the gall fauna associated to Nothofagus spp., as has been seen in other systems (Abrahamson et al. 2003).

Wherever basic taxonomic knowledge is scarce, as it is for the TFSSA, the description of distributional patterns of species richness and abundance can be more informative than the number of species itself. Hence, below we present two data sets aimed to describe general geographic patterns and mechanism driving gall species richness and abundance associated to common native host-plant species of the TFSSA.

\subsection{Gall Species Richness Across an Elevation Gradient in Northern Patagonia, Argentina}

Agreement in worldwide distributional patterns can help us elucidate the causes driving gall species diversification and assign a primary function to the adaptation of gall-inducing structures inside plant tissues. Several studies, along altitudinal gradients, have shown that galling species richness increases as temperature and dryness increases (e.g., Fernandes and Price 1988; Fernandes and Lara 1993; Lara and Fernandes 1996), probably driven by fewer enemies (e.g., fungal diseases and predators) in hot, dry environments (Fernandes and Price 1992). This trend, together with the known peak of gall diversity at intermediate latitudes (Price et al. 1998), has been used to hypothesize that galls may function primarily as a way of protecting insects from 'hygrothermal stress' in relatively enemy-free, hot and dry environments (Price et al. 1998; Fernandes and Price 1991). Yet, these trends do not apply to all ecosystems explored (e.g., Blanche 2000; Blanche and Ludwig 2001; Carneiro et al. 2005), implying that other factors might also play a relevant role.

In this section, we present data of gall species richness associated to native woody species surveyed across an elevation gradient, spanning from 760 to 1,760 m.a.s.l., in the Nahuel Huapi National Park region $\left(41^{\circ} \mathrm{S}\right.$ in northern Patagonia, Argentina). In this area, we sampled 30 sites around the Nahuel Huapi Lake ( 780 m.a.s.l.) from the Chilean border to the steppe, and 35 higher sites belonging 
to three mountains sampled every $80 \mathrm{~m}$, from 880 to $1,760 \mathrm{~m}$.a.s.l. A total of 46 different native woody species and 44 gall morphospecies were recorded, using the methods previously described (see also Price et al. 1998). The forest surveyed were dominated by the tree species Austrocedrus chilensis (Cupressaceae), Nothofagus dombeyi, N. pumilio and N. antartica, and common encountered shrub genera were Baccharis, Berberis, Escallonia, Gautheria, Maythenus, and Schinus, among others. For a list of the 44 gall morphospecies included in this study, and their host-plants, see Tables 21.1 and 21.2 (species marked with asterisk under the tissue column).

This work revealed that $\sim 40 \%$ of the native woody flora $(\mathrm{N}=18)$ hosted between one and six gall morphospecies each (described in Tables 21.1 and 21.2), and that the relationship between gall species richness and elevation varied among scales. Linear regressions showed that gall species richness decreased with elevation $\left(R^{2}=0.19, p<0.0003\right.$, Fig. 21.6a), at a rate of one gall species less every $220 \mathrm{~m}$. This trend could be driven by a decrease in the number of available woody host-plant species as we increased in elevation, which showed a decline of one woody species less every $85 \mathrm{~m}\left(R^{2}=0.55, p<0.0001\right.$, Fig. 21.6b); yet, many intrinsic and extrinsic variables that correlate with elevation remain to be tested to assess the causal factor/s of that relationship (see below). Nonetheless, this decreasing trend may not be supported by every one of the host-plants surveyed. For instance, for N. pumilio, a dominant canopy tree widely distributed across that elevation gradient, we observed the opposite trend with gall species richness increasing as its host-plant reaches higher altitudes $\left(R^{2}=0.35, p<0.001\right.$, Fig. 21.6c), with similar trends seen for each mountain (data not shown).

The overall decrease in gall species richness with elevation agrees with the consistent pattern previously observed in different parts of the globe (Waring and Price 1990; Fernandes and Price 1991; Fernandes and Lara 1993; Price et al. 1998); however, we have not tested yet what variables may be driving this pattern. While richness of host-plant species can be a potential factor (e.g. Santos de Araújo 2011), a negative relationship between altitude and gall species richness might be dependent on differential proportion of xeric versus mesic habitats, nutrient availability, variable top-down control of gall populations, and/or plant resistance traits among others (Fernandes and Price 1991, 1992; Blanche and Ludwig 2001; Cuevas-Reyes et al. 2004; Fernandes et al. 2004). In our study site, the increase in altitude is correlated with a decrease in temperature and plant species richness but not necessary by an increase in precipitation, implying that the TFSSA may not support the 'hygrothermal stress' hypothesis. In this regard, it was interesting to see that for a single host-plant, N. pumilio, the trend was actually opposite (Fig. 21.6c), suggesting that a combination of climatic and plant species traits may likely explain the observed patterns (e.g. Bairstow et al. 2010). Subsequent studies may benefit by the high diversity of gall species present in the TFSSA, in addition to the pronounced temperature and precipitation gradients, to test the potential environmental versus ecological causes driving distributional patterns in gall diversity in these austral forests. 

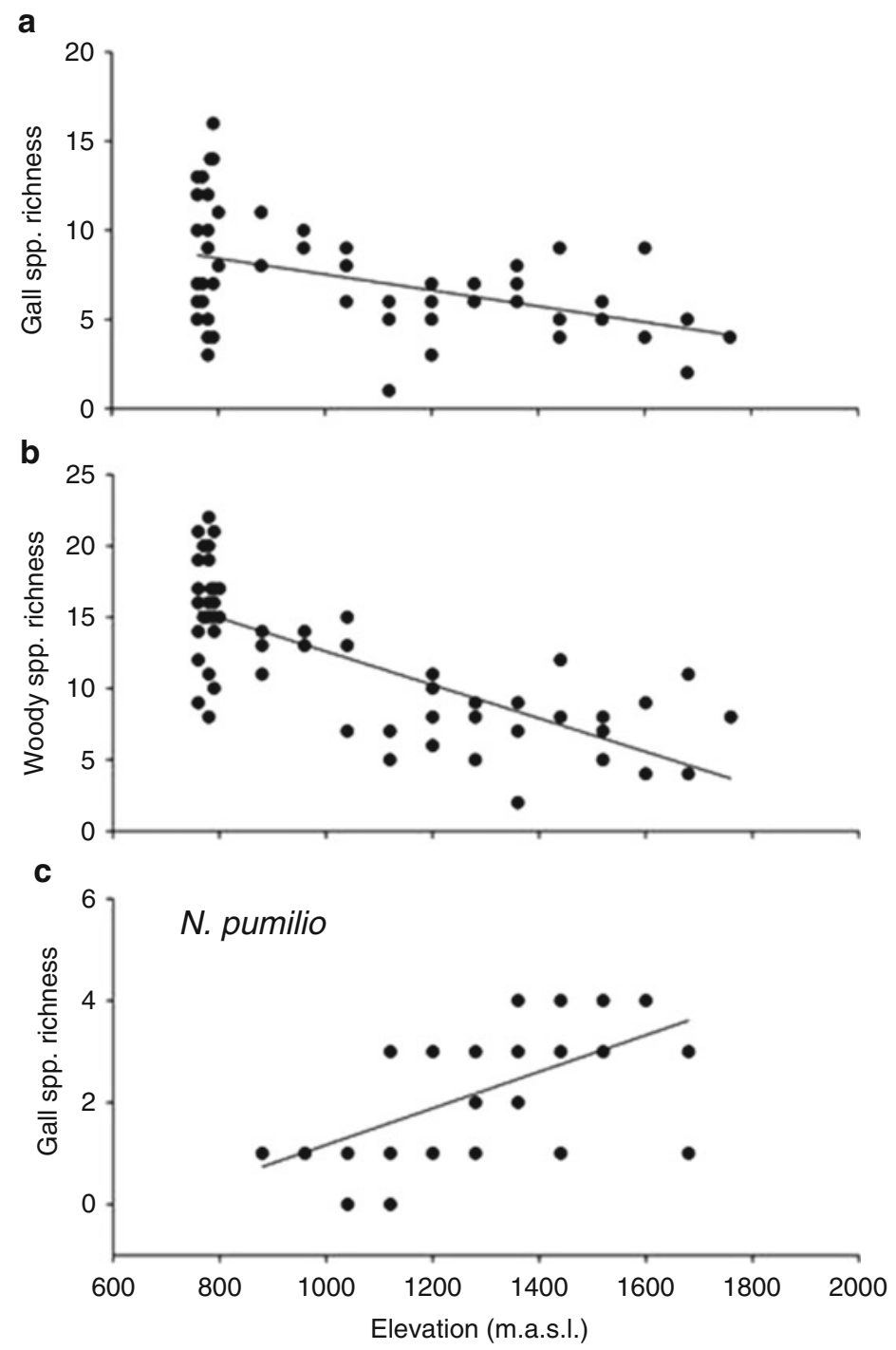

Fig. 21.6 Gall and host-plant species richness across an elevation gradient in the Nahuel Huapi National Park region ( $41^{\circ} \mathrm{S}$, Río Negro, Argentina). Plots represent the change across elevation in (a) gall species richness found in all native woody species, (b) native woody plant species richness, and (c) gall species richness found only in Nothofagus pumilio trees (Nothofagaceae)

\subsection{Geographical Variation in Gall Abundance Across Elevation and Latitudinal Gradients: The Case Study of $N$. pumilio and a Cecidomyiidae Gall Species}

Following the above regional community study, here we will focus on the mechanisms driving gall abundance of a single gall species on N. pumilio forests in Argentina $\left(38-55^{\circ} \mathrm{S}\right)$. In general, the studies evaluating geographical patterns of galling insects 

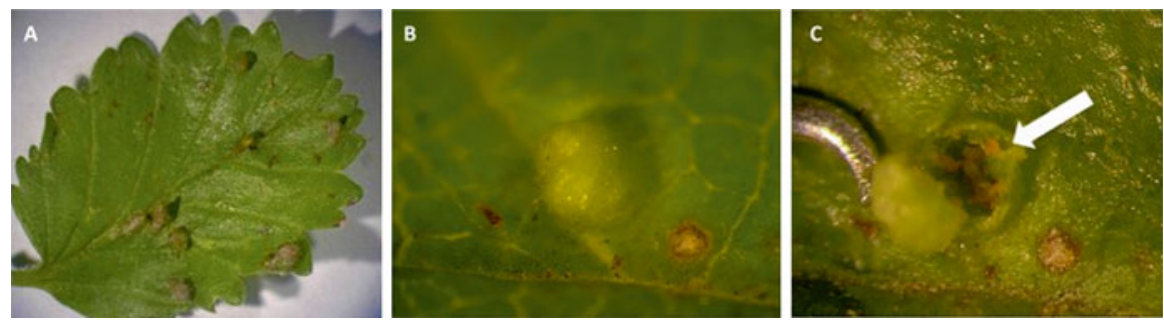

Fig. 21.7 Galls performed by a midge gall larvae (Diptera) in a leaf of Nothofagus pumilio (Nothofagaceae). (a) A dorsal leaf of $N$. pumilio with multiple midge galls (20x), (b) close up of a single midge gall close to a leaf vein $(60 \times)$, and (c) midge gall open showing several orange Cecidomyiidae larvae (60x) (Photos by Lucas A. Garibaldi)

focus on species richness, whereas drivers of gall abundance have been less studied. Nevertheless, the effects of gall inducers on plant fitness (Marini-Filho and Fernandes 2011; Viana et al. 2013), and therefore on agriculture or forestry may be strongly regulated by gall abundance. Specifically, we will explore the role of temperature and precipitation shaping latitudinal and elevation gradients in the abundance of a gall midge species (Diptera, Cecidomyiidae) (Fig. 21.7) associated to $N$. pumilio, the geographically most extended species of Nothofagus in the region.

Temperature has been singled out as the dominant abiotic factor affecting insect abundance (Bale et al. 2002), since it affects insects directly through development and survival, and indirectly by affecting, for example, their host plants and parasitoids. In the lowland tropics, mean annual temperature is close to the physiological optimal of insects; therefore, increases or decreases in temperature should reduce insect abundance (Deutsch et al. 2008). Alternatively, at temperate latitudes (or high elevations), annual mean temperature is suboptimal for insects; and therefore, increases in temperature when moving towards lower latitudes or lower elevations should promote insect abundance ("temperature hypothesis", Deutsch et al. 2008). So far, evidence for galling insects is consistent with the temperature hypothesis, as higher species richness of galling insects was found at lower, warmer elevations (e.g. Fernandes and Lara 1993; Price et al. 1998). A similar trend was also found for the abundance of free living insects and herbivory rates in $N$. pumilio forests of Patagonia (Garibaldi et al. 2011a, b); and thus, it is possible that temperature would be a good predictor for galling insects.

Yet, given their concealed life form (Sinclair and Hughes 2010), gall inducers are supposed to be less susceptible to variation in abiotic factors during the galling phase than free living insects. Accordingly, it has been proposed that the gall forming habit is an adaptation to hygrothermal stressful conditions, namely low humidity and high temperature ("harsh environmental hypothesis"; Fernandes and Price 1988). Nonetheless, gall inducers may respond to hygrothermal stress in a similar way to free living insects during the non-galling phase, such as diapause. Patterns of species richness of galling insects across precipitation gradients provide controversial evidence for the harsh environmental hypothesis (e.g. Fernandes and Price 1988; Blanche 2000). Inconsistencies among studies may be a consequence of different 
prevalence of galling insects on diverse plant taxa, or intra-specific variation in plant traits (Blanche 2000) due to soil fertility among other factors. For example, it was found that hypersensitivity reaction of plants can kill more than $90 \%$ of the galls, while natural enemies played a minor role (Fernandes 1998; Santos et al. 2008).

To explore these questions, we performed two independent observational studies. The first study focused on the latitudinal pattern of gall abundance across 48 sites between $38^{\circ}$ and $55^{\circ} \mathrm{S}$, whereas the second one focused on the elevation pattern of gall abundance in each of six mountains located across a precipitation gradient in northern Patagonia (see Garibaldi et al. 2011a, b). If temperature is suboptimal for insects in these forests (temperature hypothesis, Deutsch et al. 2008), gall abundance will increase with temperature at lower latitudes and lower elevations. In contrast, the harsh environmental hypothesis predicts that the positive effects of rising temperature would be evident in drier sites, as reflected by a negative statistical interaction between temperature and precipitation, and an overall higher galling abundance in drier sites (Fernandes and Price 1988). By comparing trends in the latitudinal and elevation studies, we reduce the possible influence of confounding factors in our conclusions. For example, along latitude, temperature varies concomitantly with photoperiod (an important driver of diapause); however, along elevation, temperature varies drastically but photoperiod does not change. In addition, the wide latitudinal range and the general monospecific nature of $N$. pumilio forests, provide a great opportunity to evaluate the above hypotheses because spatial covariation in gall abundance, leaf traits, and abiotic factors are not confounded with spatial changes in tree community composition. For both studies, we present data sampled during 2007, as similar results were found for previous years (Garibaldi et al. 2011a, b).

In the latitudinal study, we fitted models including latitude, longitude, and their interaction as predictors of gall frequency (percentage of leaves with galls) or gall density (number of galls per leaf). These models adequately represented the spatial structure of gall abundance, as semivariogram analyses demonstrated no spatial correlation in the residuals, as well as isotropy (Zuur et al. 2009). We found that both gall frequency and gall density increased with latitude (Fig. 21.8; gall frequency: $\mathrm{F}_{1.44}=5.9, p=0.019$; gall density: $\left.\mathrm{F}_{1.44}=5.5, p=0.023\right)$. The effect of latitude was greater in the east than in the west, as reflected by a negative statistical interaction between the effects of latitude and longitude (gall frequency: $F_{1.44}=5.9$, $p=0.019$; gall density: $\left.\mathrm{F}_{1.44}=5.6, p=0.023\right)$. Overall, both gall frequency and gall density increased to the west (gall frequency: $\mathrm{F}_{1.44}=6.7, p=0.021$; gall density: $\mathrm{F}_{1.44}=5.4, p=0.025$ ), and this effect was greater at northern sites. In agreement, although focussing on species richness rather than gall abundance, a study performed from $16^{\circ}$ to $30^{\circ} \mathrm{S}$ near the Brazilian coast found an increase in species richness of galling insects with latitude on Baccharis dracunculifolia, probably because galling insects associated with Baccharis radiated in southern Brazil (Fagundes and Fernandes 2011).

In the elevation study, we fitted models including elevation, site (each of six mountains), and their interaction as predictors of gall frequency or gall density. As above, semivariogram analyses demonstrated no spatial correlation in the residuals, 

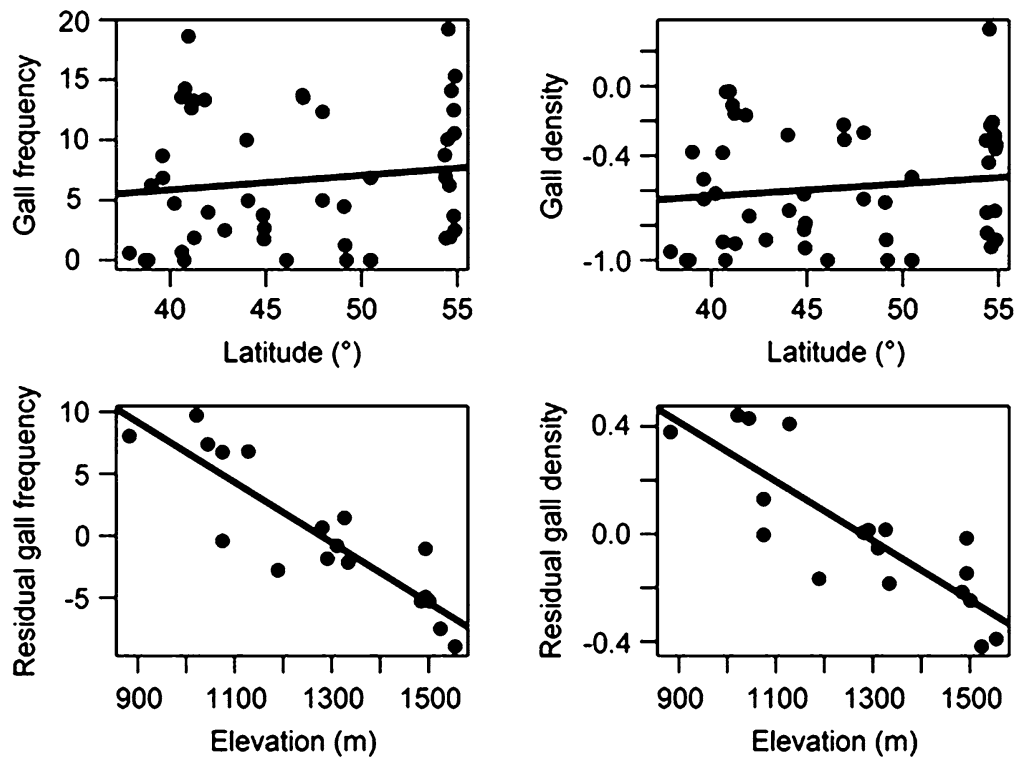

Fig. 21.8 Gall frequency (\% of leaves with galls) and gall density (no. of galls per leaf) show a slight increase with latitude but a strong decrease with elevation on Nothofagus pumilio (Nothofagaceae) forests. Gall density was $\log 10$ transformed to achieve normality and homoscedascity assumptions in the latitudinal study. Residues from mountain (site) effects are plotted for gall frequency and gall density in the elevation study

as well as isotropy. We found that both gall frequency and gall density decreased strongly with elevation (Fig. 21.8; gall frequency: $\mathrm{F}_{1.6}=120, p<0.001$; gall density: $\left.\mathrm{F}_{1.6}=73, p<0.001\right)$. At $1,000 \mathrm{~m}$, gall frequency and gall density were on average

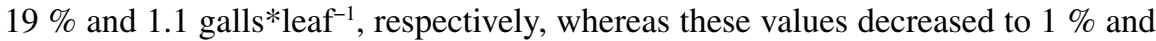
0.028 galls $^{*}$ leaf $^{-1}$ at $1,500 \mathrm{~m}$, respectively (Fig. 21.8). We also found differences in gall frequency and gall density among the six mountains (gall frequency: $\mathrm{F}_{5.6}=6.5$, $p=0.020$; gall density: $\mathrm{F}_{5.6}=6.8, p=0.018$ ), and the effect of elevation varied in magnitude across mountains but it was always negative (gall frequency: $\mathrm{F}_{5.6}=4.7$, $p=0.044$; gall density: $\mathrm{F}_{5.6}=4.3, p=0.051$ ). These results are in agreement with the decrease in species richness of galling insects reported across elevation gradients (e.g., Price et al. 1998; Fernandes and Lara 1993), mostly in tropical ecosystems.

When looking at the mechanisms underlying these patterns, interesting results emerged. Gall frequency increased with temperature across the sites of the elevational study, whereas no association was found in the latitudinal study (Fig. 21.9). Precipitation did not co-vary with gall frequency in either study (Fig. 21.9). The same results were observed for gall density (data not shown for brevity). The absence of association between gall abundance and climate in the latitudinal study (Fig. 21.9) is in agreement with the weak association between gall abundance and latitude (Fig. 21.8), probably because of concomitant variation in other drivers of gall abundance, such as leaf traits or photoperiod. On the other hand, results for the 

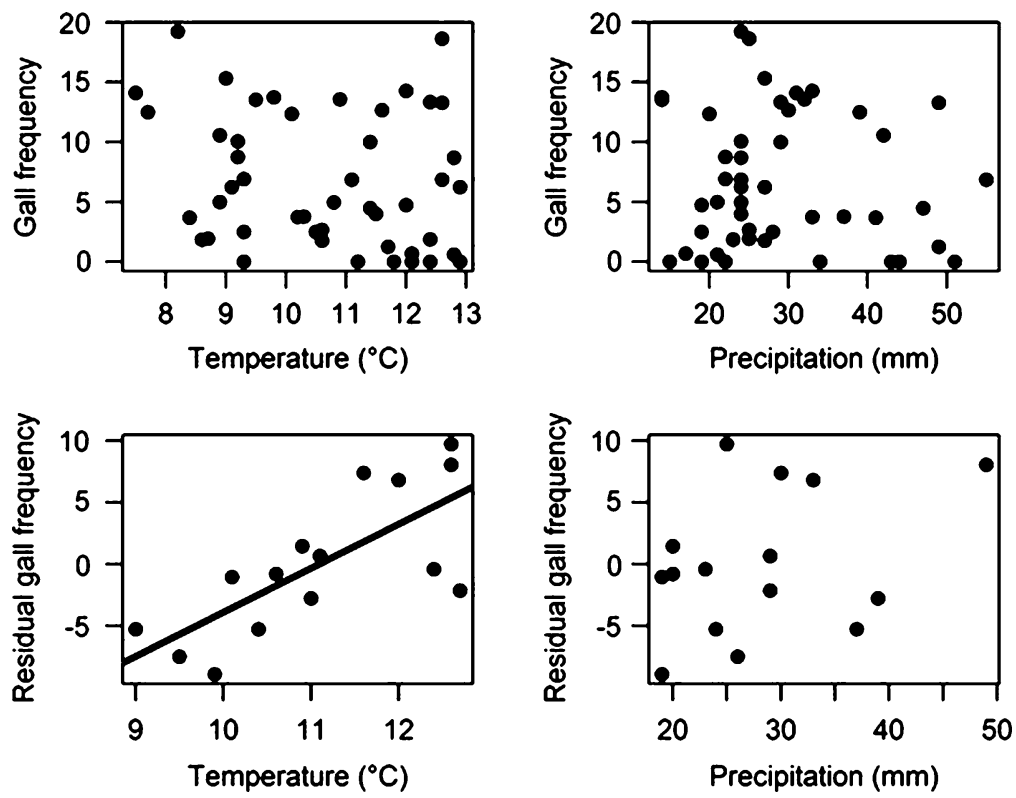

Fig. 21.9 Gall frequency (\% of leaves with galls) as a function of mean temperature and precipitation on Nothofagus pumilio (Nothofagaceae) forests in the latitudinal study (upper panels) and the elevation study (lower panels). Both temperature and precipitation are for the warmest (and driest) quarter of the year (i.e. summer); the same results were found for annual mean temperature and annual precipitation. Residues from mountain (site) effects are plotted for gall frequency in the elevation study. The solid line is plotted after significant linear relationship between variables

elevational study are in agreement with the temperature hypothesis, suggesting that temperature limitation on gall abundance is reduced at lower elevations. In addition, the absence of association between gall abundance and precipitation in the elevation study does not support the harsh environmental hypothesis. The consistent decrease in species richness of galling insects with elevation in other studies (Fernandes and Lara 1993; Price et al. 1998), conjointly with the controversial results for species richness as a function of precipitation gradients (Blanche 2000; Fernandes and Price 1988), also give higher support for the temperature hypothesis over the harsh environmental hypothesis as a main driver of the spatial variation in richness and abundance of galling insects.

\subsection{Conclusions}

The study of gall diversity and the biotic and abiotic factors that shape their distribution in these austral forests offer an exciting and fertile field for future research. Here, we presented data for 90 morphospecies of gall inducers; associated to 39 native woody plant species (21 genera, 15 families; Tables 21.1 and 21.2), most of which have never 
been previously reported. Yet, because we have just started to perform systematic field surveys across taxa and geographic ranges, we believe this number probably underestimates the actual richness of this guild for the TFSSA.

To put our results into perspective, we took advantage of species diversity estimations. Applying Espírito-Santo and Fernandes (2007)'s formulas designed to estimate gall species diversity worldwide (ranging from 21,000 to 211,000), and assuming a positive relationship between plant richness and gall species diversity for these forests, species estimations for the TFSSA should range from $\sim 8$ to 84 gall species. This estimate originates from the 167 native woody species reported for this region (Aizen and Ezcurra 2008) and is conservative given that it excludes herbaceous plant species ( 1,300 spp.), and that the formula only estimates galling insects and not other gall inducers such as Acari, Nematodes and Bacteria. Similarly, just for the genus Nothofagus, with nine species, the expected gall insect diversity should lead to a range of $<1-5$ estimated gall species. Based on these estimations, we conclude that the total number of species reported here for South American Nothofagus (43 spp.) is noticeably larger than expected; whereas the described biodiversity of galling insects associated to all other native woody species (47 spp.) fall within the estimates. Moreover, while it is uncertain if this high gall diversity in South American Nothofagus is expected or not based on other Australasian Nothofagus, it is at least high in comparison with other common temperate and tropical dominant tree genus worldwide (e.g., Acacia (Fabaceae) N=84, Bairstow et al. 2010; Eucalyptus (Myrtaceae) N=30+, Blanche and Westoby 1996; Quercus (Fagaceae) N=1,000, Stone et al. 2009; Salix (Salicaeae) N=200, Nyman 2000). From these observations two questions emerge: (i) Are we closer to a comprehensive list of gall inducers for the TFSSA?, and (ii) Why does Nothofagus spp. host such a rich community of galls?

Although we know that reaching a comprehensive inventory of gall inducer diversity is implausible for almost any ecosystem worldwide, we believe that a rich fauna of galling insects associated with the TFSSA still remains to be described. To date, less than $25 \%$ of the native woody flora has been surveyed for gall inducers and herbaceous species are nearly unexplored, suggesting that the known diversity of gall inducers reported here might be at least a fourth of the actual diversity present in these forests. Moreover, the incipient trend of higher gall biodiversity in the most specious host-plant genus surveyed such us Berberis (Berberidaceae) and Gaultheria (Ericaceae) suggests that further field studies focused on other native specious genera [e.g., Azara (Flacourtiaceae), Baccharis (Asteraceae), Drimys (Winteraceae), Escallonia (Escalloniaceae), Myrceugenia (Myrtaceae), Pernettya (Ericaceae), and Ribes (Grossulariaceae) among others] may lead to the discovery of undescribed species. Lastly, geographically explicit studies are still scarce and thus, we lack knowledge regarding geographic variation in gall species richness across space. Hence, we highlight the need for expanding the ecological and taxonomic characterization of new as well as currently described species.

Exploring the causes responsible for the rich community of gall inducers associated to Nothofagus spp. may provide support for various proposed hypotheses explaining patterns of gall diversification worldwide. First, the plant taxon age hypothesis 
proposes that older host taxa should host richer gall faunas, since greater evolutionary time leads to an increase in number of speciation events (Fernandes 1992). Given that South America has been identified as the likely ancestral area of Nothofagus (Swenson et al. 2000), future comparisons of gall faunas associated to Nothofagus across continents or associated with other younger genera of the TFSSA warrant promising results. Second, the taxon size hypothesis predicts that the most diverse host taxa have greater galling richness, assuming that each host species is a potential niche for insects (Mendonça 2007). Our data, preliminary supports this trend for the TFSSA with the most diverse host-plant genera hosting richer gall faunas, but today the Nothofagus genus with nine host-plant species still rise as a super-host as compared to other specious genera of the TFSSA. Hence, other factors besides taxon size may explain this pattern. Lastly, the taxon geographical area hypothesis expect a positive relationship between host-plant range size and local or regional gall species richness, as seen in Quercus (Cornell 1985a, b) and Eucalyptus (Blanche and Westoby 1996). Although this relationship was not supported by our data so far (Fig. 21.5), studies designed just to test this pattern should be performed before discarding this hypothesis. Testing among these hypotheses would definitively enhance our knowledge of the biogeography of the TFSSA and the causes driving gall diversification worldwide.

Regarding gall geographic distribution patterns, our preliminary data on the TFSSA supported existent trends of decrease gall species richness and/or abundance with elevation and latitude (e.g., Waring and Price 1990; Fernandes and Price 1991; Fernandes and Lara 1993; Price et al. 1998). For the most part, although not fully tested yet, this trend is believed to be driven by decrease temperature and host-plant species richness and composition as we increase in altitude and latitude, but not by changes in precipitation. Yet, studies incorporating soil fertility and plant physical and chemical traits are expected to enhance our understanding of the drivers shaping the observed patterns (i.e. Ribeiro and Basset 2007; Lavandero et al. 2009; Bairstow et al. 2010). Furthermore, we have to be cautious with the implications of these preliminary trends since they are based on the response to elevation of a small fraction of the gall community of the TFSSA (those found in northern Patagonia, Argentina) and a single midge gall species across latitudinal and elevation gradients (i.e. last two sections, respectively).

Spatial distributions of gall species is expected to be the result of complex interactions between species-specific population demography, behavioral traits, phylogenetic and biogeographic history, and species interactions. Hence, we believe that each gall species and local gall assemblages, across the TFSSA, can show variable patterns. For instance, here we showed for $N$. pumilio, the geographically most extended species of Nothofagus in the region, that while gall richness increased with elevation at northern latitudes ( $\mathrm{N}=0$ to 4 gall spp., Fig. 21.6c), gall abundance of a midge gall decreased with both increasing elevation and latitude (Fig. 21.8). This, seemingly contradictory pattern might be explained by host-plant traits and ecological interactions. Plant traits adaptive in higher elevations such as higher constitutive defenses, low tissue turnover, and resprouting ability may indirectly favor higher gall species richness, while gall abundance might be controlled by other plant traits 
such as leaf surface area and/or variable top-down forces. For instance, gall inducers in N. pumilio forests are exposed to other less common natural enemies, such as the case of the endemic Austral Parakeet (Enicognathus ferrugineus), which has been observed consuming hymenoptera larvae of Aditrochus fagicolus leaf galls and Homoptera, Lepidoptera, and Diptera larvae present in seed galls, mainly during its pre-reproductive period, when other resources are scarce (Díaz and Peris 2011). Thus, if at higher elevations gall inducers encounter more susceptible host species but higher predation rates, due to lack of other nutritious foods, that might explain the increased richness but lower gall abundance observed. Given the rich gall fauna hosted by the flora of the TFSSA, especially Nothofagus spp., and their exposure to extreme environmental gradients, these temperate forests represent a unique opportunity to test hypotheses focused on the relative contribution of biotic and abiotic factors driving gall species distribution patterns.

Finally, knowledge regarding galls taxonomy and higher trophic interactions is at this time extremely limited, but also guarantees a fruitful new area of research. In particular, higher trophic interactions among gall inducers, parasitoids, hyperparasitoids, and inquilines are of particular taxonomic and conservation interests given that the biodiversity of this group can be enormous (Price et al. 1987). Currently, given the high probability of endemism for this group and based on recent publications (Moreno et al. 1999; Burckhardt and Basset 2000; NievesAldrey et al. 2009; Buffington and Nieves-Aldrey 2011), we expect that several species of gall inducers as well as their associated higher trophic communities might be new to science. Following a more in depth taxonomic characterization of this fauna, phylogenetic and biogeographic studies of key gall families (i.e. Pteromalidae) may contribute to reconstruct the evolutionary history of these forests, as has been done for example with other obligated parasites of Nothofagus spp. (i.e. Cyttaria spp., Peterson et al. 2010).

In sum, the richness and diversity of this gall community has just started to be revealed and many questions still remain to be answered about the ecological and evolutionary interactions of gall inducers in the TFSSA. We identify the following four areas to be of particular importance. First, it is clear from this chapter that we lack critical taxonomic knowledge of the gall fauna of the TFSSA; and thus, considerable efforts should be allocated to improve this basic knowledge. Second, assessment of the factors explaining Nothofagus' rich gall fauna as well as among species variation in gall diversity may shed light on the proximate and ultimate drivers of gall species diversification and adaptation. Third, the biodiversity of higher trophic levels (i.e. parasitoids, hyperparasitoids, and inquilines) associated to this unique gall fauna and their top-down control need to be further elucidated. Lastly, disentangling the biotic and abiotic components influencing geographical patterns in gall inducers' diversity may help us to understand how natural selection actually shapes the evolution of this herbivore guild. In particular, a fruitful area of research in the TFSSA is related to studies focused on key natural history traits of the gall inducers as well as of the host-plants to assess the relative contribution of these biotic variables over other relevant environmental factors shaping the latitudinal and elevation gradients observed here. 


\section{References}

Abrahamson WG, Hunter MD, Melika G et al (2003) Cynipid gall-wasp communities correlate with oak chemistry. J Chem Ecol 29:209-223

Aizen MA, Ezcurra C (1998) High incidence of plant-animal mutualisms in the temperate forest of southern South America, biogeographical origin and present ecological significance. Ecol Austral 8:217-236

Aizen MA, Ezcurra C (2008) Do leaf margins of the temperate forest flora of southern South America reflect a warmer past? Glob Ecol Biogeogr 17:164-174

Aizen MA, Vázquez DP, Smith-Ramírez C (2002) Historia natural de los mutualismos plantaanimal del Bosque Templado de Sudamérica Austral. Rev Chil Hist Nat 75:79-97

Amigo J, Rodriguez-Guitian MA (2011) Bioclimatic and phytosociological diagnosis of the species of the Nothofagus genus in South America. Int J Geobot Res 1:1-20

Armesto JJ, Rozzi R (1989) Seed dispersal syndromes in the rain forest of Chiloé: evidence for the importance of biotic dispersal in a temperate rain forest. J Biogeogr 16:219-226

Armesto JJ, Smith-Ramírez C, Carmona MR et al (2009) Old-growth temperate rainforests of South America: conservation, plant-animal interactions, and baseline biogeochemical processes. In: Wirth C et al (eds) Old-growth forests, ecological studies 207. doi:10.1007/9783-540-92706-8_16, \#

Arroyo MTK, Cavieres L, Peñaloza A et al (1996) Relaciones fitogeográficas y patrones regionales de riqueza de especies en la flora del bosque lluvioso templado de Sudamérica. In: Armesto JJ, Villagrán C, Arroyo MTK (eds) Ecología de los bosques nativos de Chile. Editorial Universitaria, Santiago de Chile, pp 71-99

Arroyo MTK, Marquet PA, Marticorena C et al (2004) Chilean winter rainfall-Valdivian forests. In: Mittermeier RA, Gil PR, Hoffmann M et al (eds) Hotspots revised: earth's biologically wealthiest and most threatened ecosystems. CEMEX, México, pp 99-103

Bairstow KA, Clarke KL, McGeoch MA et al (2010) Leaf miner and plant galler species richness on Acacia: relative importance of plant traits and climate. Oecologia 163:437-448

Bale JS, Masters GJ, Hodkinson IAND et al (2002) Herbivory in global climate change research: direct effects of rising temperature on insect herbivores. Glob Chang Biol 8:1-16

Barrancos ML, Moncaglieri R, Farji-Brener A (2008) Infección por agallas y producción de inflorescencias en el arbusto Schinus patagonicus. Ecol Austral 18(1):133-137

Blanche KR (2000) Diversity of insect-induced galls along a temperature-rainfall gradient in the tropical savannah region of the Northern Territory, Australia. Austral Ecol 25:311-318

Blanche KR, Ludwig JA (2001) Species richness of gall-inducing insects and host plants along an altitudinal gradient in Big Bend National Park, Texas. Am Midl Nat 145(2):219-232

Blanche KR, Westoby M (1996) The effect of the taxon and geographic range size of host eucalypt species on the species richness of gall-forming insects. Aust J Ecol 21:332-335

Buffington M, Nieves-Aldrey JL (2011) Revision of Plectocynipinae (Hymenoptera: Figitidae) with descriptions of a new genus and three new species from Chile. Proc Entomol Soc Wash 113(2):91-108

Burckhardt D, Basset Y (2000) The jumping plant-lice (Hemiptera, Psylloidea) associated with Schinus (Anacardiaceae): systematics, biogeography and host plant relationships. J Nat Hist 34:57-155

Cabrera AL, Willink A (1973) Biogeografía de América Latina, Biology series, Monograph 13. General Secretary of the Organization of American States, Washington, DC

Carneiro MAA, Fernandes GW, De Souza OFF (2005) Convergence in the variation of local and regional galling species richness. Neotrop Entomol 34(4):547-553

Carrillo R, Cerda L (1987) Zoofitófagos en Nothofagus chilenos. Bosque 8(2):99-103

Cerda E, Angulo A (2002) Insectos asociados a bosques del centro-sur de Chile. In: Baldini A, Pancel L (eds) Agentes de daño en el bosque nativo. Editorial Universitaria, Santiago

Cobb NA (1922) Two tree-infesting nemas of the genus Tylenchus. An Zool Apl 9:27-35 
Cornell HV (1985a) Local and regional richness of cynipine gall wasps on California Oaks. Ecology 66:1247-1260

Cornell HV (1985b) Species assemblages of cynipid gall wasps are not saturated. Am Nat 126:565-569

Csóka G, Stone GN, Melika G (2005) The biology, ecology and evolution of gall wasps. In: Raman A, Schaeffer CW, Withers TM (eds) Biology, ecology and evolution of gall-inducing arthropods. Science Publishers, Inc, Enfield, pp 569-636

Cuevas-Reyes P, Quesada M, Siebe C et al (2004) Spatial patterns of herbivory by gall-forming insects: a test of the soil fertility hypothesis in a Mexican tropical dry forest. Oikos 107:181-189

Da Tavares Silva J (1915) Cecidologie Argentine. Broteria 13:88-128

De Santis L, Fidalgo P, Ovruski S (1993) Himenópteros parasitoides de los géneros Aditrochus Ruebsaamen y Espinosa Gahan (Insecta, Hymenoptera, Pteromalidae) asociados a agallas en Nothofagus (Fagaceae) del sur de Argentina y Chile. Acta Entomol Chil 18:133-146

Deutsch CA, Tewksbury JJ, Huey RB et al (2008) Impacts of climate warming on terrestrial ectotherms across latitude. Proc Natl Acad Sci-Biol 105:6668-6672

Díaz NB (1976) Estudio ecologico y sistematico de cynipoideos Neotropicales I. (Hymenoptera). Plectocynips longicornis gen y sp $n$. Neotropical 22:99-102

Díaz NB (1981) Cinpoideos galígenos e inquilinos de la República Argentina. Rev Soc Entomol Argent 39:221-226

Díaz NB, De Santis L (1975) Las agallas esferoidales del algarrobo de Chile. Neotropica 21:89-93

Díaz S, Peris S (2011) Consumption of larvae by the Austral Parakeet (Enicognathus ferrugineus). Wilson J Ornithol 123:168-171

Drathen T (1958) Apuntes sobre las agallas del Colliguay. Rev Univ Chile 39:1

Echeverría C, Coomes D, Salas J et al (2006) Rapid deforestation and fragmentation of Chilean temperate forests. Biol Conserv 130:481-494

Espírito-Santo MM, Fernandes GW (2007) How many species of gall-inducing insects are there on earth, and where are they. Ann Entomol Soc Am 100:95-99

Fagundes M, Fernandes GW (2011) Insect herbivores associated with Baccharis dracunculifolia (Asteraceae): responses of gall-forming and free-feeding insects to latitudinal variation. Rev Biol Trop 59:1419-1432

Fernandes GW (1992) Plant size family and age effects on insular gall-forming species richness. Glob Ecol Biogeogr 2:71-74

Fernandes GW (1998) Hypersensitivity as a phenotypic basis of plant induced resistance against a galling insect (Diptera: Cecidomyiidae). Environ Entomol 27:260-267

Fernandes GW, Lara ACF (1993) Diversity of Indonesian gall-forming herbivores along altitudinal gradients. Biodivers Lett 1:186-192

Fernandes GW, Price PW (1988) Biogeographical gradients in galling species richness: tests of hypotheses. Oecologia 76:161-167

Fernandes GW, Price PW (1991) Comparisons of tropical and temperate galling species richness: the roles of environmental harshness and plant nutrient status. In: Price PW, Lewinsohn TM, Fernandes GW et al (eds) Plant-animal interactions: evolutionary ecology in tropical and temperate regions. Wiley, New York, pp 91-115

Fernandes GW, Price PW (1992) The adaptive significance of insect gall distribution: survivorship of species in xeric and mesic habitats. Oecologia 90:14-20

Fernandes GW, Carneiro MAA, Lara ACF et al (1996) Galling insects on Neotropical species of Baccharis (Asteraceae). Trop Zool 9(2):315-332

Fernandes GW, Caldeira Castro FM, Faria ML, Marques ESA, Barcelos Greco MK (2004) Effects of hygrothermal stress, plant richness, and architecture on mining insect diversity. Biotropica 36:240-247

Fuentes-Contreras E, Gianoli E, Caballero PP et al (1999) Influence of altitude and host-plant species on gall distribution in Colliguaja spp. (Euphorbiaceae) in Central Chile. Rev Chil Hist Nat 72:305-313 
Garibaldi LA, Kitzberger T, Chaneton EJ (2011a) Environmental and genetic control of insect abundance and herbivory along a forest elevational gradient. Oecologia 167:117-129

Garibaldi LA, Kitzberger T, Ruggiero A (2011b) Latitudinal decrease in folivory within Nothofagus pumilio forests: dual effect of climate on insect density and leaf traits? Glob Ecol Biogeogr 20:609-619

Gentili M, Gentili P (1988) Lista comentada de los insectos asociados a las especies Sudamericanas del genero Nothofagus. Monografías de la Academia Nacional de Ciencias Exactas, Físicas y Naturales, Buenos Aires 4:85-106

Gonzales WL, Caballero PP, Medel R (2005) Galler-induced reduction of shoot growth and fruit production in the shrub Colliguaja integerrima (Euphorbiaceae). Rev Chil Hist Nat 78:393-399

Grandón F (1996) Análisis fitosanitario de los Nothofagus de Chile, desde el punto de vista entomológico. Tesis de Grado para optar al Título de Ingeniero Forestal, Facultad de Ciencias forestales, Universidad Austral de Chile, Chile

Grau J (1995) Aspectos geográficos de la flora de Chile. In: Marticorena C, Rodríguez R (eds) Flora de Chile. Universidad de Concepción, Concepción, pp 63-83

Grez AA, Simonetti JA, Bustamante RO (2006) Biodiversidad en ambientes fragmentados de Chile: patrones y procesos a diferentes escalas. Editorial Universitaria, Santiago

Hinojosa LF, Villagrán C (1997) Historia de los bosques del sur de Sudamérica, I: Antecedentes paleobotánicos, geológicos y climáticos del Terciario del cono sur de América. Rev Chil Hist Nat 70:252-239

Hoffmann A (1978) Flora Silvestre de Chile: zona central. Ediciones Fundación Claudio Gay, Santiago de Chile

Hoffmann A (1982) Flora Silvestre de Chile: zona araucana. Ediciones Fundación Claudio Gay, Santiago de Chile

Houard C (1933) Les Zoocécidies des Plantes de l'Amerique du Sud et de l'Amerique Centrale. Librairie Scientifique A. Hermann, Paris

Kieffer JJ (1904a) Description de quelques Cynipides exotiques dont l'un forme un genre nouveau. B Soc Histoire Naturelle de Metz 23:59-66

Kieffer JJ (1904b) Description de quelques Cynipides exotiques dont l'un forme un genre nouveau. Rev Chil Hist Nat 8:43

Kieffer JJ, Herbst P (1905) Ueber gallen und gallenerzeuger aus Chile. Zs Wiss Insektenbiol Husum 10(81):63-66

Kieffer JJ, Herbst P (1906) Description de galles et d'Insectes gallicoles du Chili. Bruxelles Ann Soc Sci 30:223-236

Kieffer JJ, Herbst P (1909) Ueber einige neue Gallen und Gallenerzeuger aus Chile. Centralbl Bakt Iena 23(2):119-126

Kieffer JJ, Herbst P (1911) Ueber gallen und gallentiere aus Chile. Centralbl Bakt Iena 2 t 29:696-703

Kieffer JJ, Jörgensen P (1910) Gallen und Gallentiere aus Argentinien. Centralbl Bakt Iena t 27(2):362-444

Kissinger DG (2005) Review of Apioninae of Chile (Coleoptera: Curculionoidea: Apionidae). Coleopt Bull 59(1):71-90

Klein Koch C, Waterhouse DF (2000) The distribution and importance of arthropods associated with agriculture and forestry in Chile (Distribución e importancia de los artrópodos asociados a la agricultura y silvicultura en Chile). ACIAR monograph no. 68, $234 \mathrm{p}$

Kuschel G (1960) Terrestrial zoology in southern Chile. Proc R Soc Lond B Bio 152:540-550

La Salle J (2005) Biology of gall inducers and evolution of gall induction in Chalcidoidea (Hymenoptera: Eulophidae, Eurytomidae, Pteromalidae, Tanaostigmatidae, Torymidae). In: Raman A, Schaefer CW, Withers TM (eds) Biology, ecology, and evolution of gall-inducing arthropods, vol 2. Science Publishers, Inc. Enfield, New Hampshire, pp 507-537

Lara ACF, Fernandes GW (1996) The highest diversity of galling insects: Serra do Cipo, Brazil. Biodivers Lett 3:111-114

Lavandero B, Labra A, Ramírez CC et al (2009) Species richness of herbivorous insects on Nothofagus trees in South America and New Zealand. The importance of chemical attributes of the host. Basic Appl Ecol 10:10-18 
Liu Z, Ronquist F (2006) Familia Cynipidae. In: Fernández F, Sharkey MJ (eds) Introducción a los Hymenoptera de la Región Neotropical. Sociedad Colombiana de Entomología y Universidad Nacional de Colombia, Bogotá, pp 839-849

Madrid FG (1974) Rhopalomyia nothofagi Gagne, biología y daño en el roble (Diptera, Cecidomyiidae). Bull Soc Biol Concepcion 48:395-402

Manganaro A (1914) Apuntes cecidiológicos. Anales del Museo Nac Hist Nat Buenos Aires Argent 26:145-150

Marini-Filho OJ, Fernandes GW (2011) Stem galls drain nutrients and decrease shoot performance in Diplusodon orbicularis (Lythraceae). Arthropod-Plant Interact 6:121-128

Markgraf V, McGlone M, Hope G (1995) Neogene paleoenvironmental and paleoclimatic change in southern temperate ecosystems - a southern perspective. Trends Ecol Evol 10(4):143-147

Martínez E, Montenegro G, Elgueta M (1992) Distribution and abundance of two gall-makers on the euphorbiaceous shrub Colliguaja odorifera. Rev Chil Hist Nat 65:75-82

McQuillan PB (1993) Nothofagus (Fagaceae) and its invertebrate fauna - an overview and preliminary synthesis. Biol J Linn Soc 49:317-354

Mendonça MS (2007) Plant diversity and galling arthropod diversity - searching for taxonomic patterns in an animal-plant interaction in the Neotropics. Bol Soc Argent Bot 42:347-357

Mittermeier RA, Gil PR, Hoffmann M et al (2004) Hotspots revised: earth's biologically wealthiest and most threatened ecosystems. CEMEX, México

Molina GI (1782) Saggio sulla storia naturale del Chile. Bologna, in $8^{\circ}$, premiere edition, $367 \mathrm{p}, 1$ carte. Pag. 2134: galle de Baccharis

Moreno I, Vovlas N, Troccoli A (1999) A new leaf gall-nematode on Nothophagus obliqua in Chile. Nematropica 29(1):113-114

Neger FW (1900) Sobre algunas agallas nuevas chilenas. Rev Chil Hist Nat Valparaiso 4:2-3

Nieves-Aldrey JL, Grez A (2007) Two cynipids species inducing galls to herbaceous weeds (Hym., Cynipidae) introduced in Chile. Agrociencia 41:921-927

Nieves-Aldrey JL, Liljeblad J, Hernández Nieves M et al (2009) Revision and phylogenetics of the genus Paraulax Kieffer (Hymenoptera, Cynipidae) with biological notes and description of a new tribe, a new genus and five new species. Zootaxa 2200:1-40

Nyman T (2000) Phylogeny and ecological evolution of gall-inducing sawflies (Hymenoptera: Tenthredinidae). PhD dissertations in Biology, no 6, University of Joensuu. ISSN 1457-2486

Peterson KR, Pfister DH, Bell CD (2010) Cophylogeny and biogeography of the fungal parasite Cyttaria and its host Nothofagus, southern beech. Mycologia 102(6):1417-1425

Philippi RA (1873) Chilenische insekten. Ent Zig Stettin 34:296-316, gallen des Colliguai and gallen des Romero

Porter CE (1920a) Notas hemipterológicas. An Zool Apl Santiago 7:16

Porter CE (1920b) Descripción de un nuevo coccido chileno. An Zool Apl Santiago 7:33-34

Porter CE (1930) Nota acerca de un díptero chileno productor de agallas. Rev Chil Hist Nat Valparaiso 33:212-214

Price P, Fernandes GW, Waring GL (1987) Adaptive nature of insect galls. Environ Entomol 16:15-24

Price P, Fernandes GW, Lara ACF et al (1998) Global patterns in local number of insects galling species. J Biogeogr 25:581-591

Pujade-Villar J, Díaz NB (2001) Cinípidos galígenos introducidos en America del Sur (Hymenoptera: Cynipoidea: Cynipidae). Rev Soc Entomol Argent 60:209-214

Ravenna P (2000) Nothofagus rutila sp. nov., and the correct author citation of $N$. nervosa (Fagaceae). Onira 4(1):1-4

Ribeiro SP, Basset Y (2007) Gall-forming and free-feeding herbivory along vertical gradients in a lowland tropical rainforest: the importance of leaf sclerophylly. Ecography 30:663-672

Rodríguez R, Quezada M (2003) Nothofagus Blume. In: Marticorena CR, Rodriguez R (eds) Flora de Chile. Vol 2 (2). Berberidaceae-Betulaceae. Universidad de Concepción, Concepción, pp 64-75

Ronquist F (1999) Phylogeny, classification and evolution of the Cynipoidea. Zool Scr 28:139-164

Ronquist F, Nieves-Aldrey JL (2001) A new subfamily of Figitidae (Hymenoptera, Cynipoidea). Zool J Linn Soc 133:483-494 
Rübsaamen EH (1902) Pteromalidem. In: Friederischen L et al (ed) Hamburger Magalhansische Sammelreise. Hamburg, pp 1-7

Sandoval A, Beeche M (2010) Insectos asociados a los bosques de Nothofagus rutila Ravenna en el Cerro el Roble. Ministerio de Agricultura de Chile, Servicio Agrícola y Ganadero

Santos de Araújo W (2011) Can host plant richness be used as a surrogate for galling insect diversity? Trop Conserv Sci 4(4):420-427

Santos JC, Silveira FAO, Fernandes GW (2008) Long term oviposition preference and larval performance of Schizomyia macrocapillata (Diptera: Cecidomyiidae) on larger shoots of its host plant Bauhinia brevipes (Fabaceae). Evol Ecol 22:123-137

Sinclair RJ, Hughes L (2010) Leaf miners: the hidden herbivores. Austral Ecol 35:300-313

Stone GN, Hernandez-Lopez A, Nicholls JA et al (2009) Extreme host plant conservatism during at least 20 million years of host plant pursuit by oak gallwasps. Evolution 63(4):854-869

Stuardo C (1930) Observaciones sobre las agallas blancas de Baccharis rosmarinifolia Hook., y el diptero que las produce. Rev Chil Hist Nat 33:345-350

Swenson U, Hill RS, McLoughlin S (2000) Ancestral area analysis of Nothofagus (Nothofagaceae) and its congruence with the fossil record. Aust Syst Bot 13:469-478

Trotter A (1902) Descrizione di alcune galle dell'America del Sud. B Soc Bot Ital 98-107

Vergara O, Jerez V (2010) Insectos e infestaciones asociadas al follaje de Nothofagus antárctica (Forst) Oerst (Nothofagaceae) en la cuenca del río Baker, Región de Aysén, Chile. Gayana 74(2):83-93

Viana LR, Silveira FAO, Santos JC et al (2013) Nematode-induced galls in Miconia albicans: effect of host plant density and correlations with performance. Plant Species Biol 28:63-69

Villagrán C, Hinojosa LF (1997) Historia de los bosques del sur de Sudamérica, II: Análisis fitogeográfico. Rev Chil Hist Nat 70:241-267

Waring GL, Price PW (1990) Plant water stress and gall formation (Cecidomyiidae: Asphondylia spp.) on creosote bush. Ecol Entomol 15:87-95

Zuur AF, Ieno EN, Walker NJ et al (2009) Mixed effects models and extensions in ecology with R. Springer, New York 